\title{
Teacher Quality, Opportunity Gap, and National Achievement in 46 Countries
}

\author{
by Motoko Akiba, Gerald K. LeTendre, and Jay P. Scribner
}

The 2003 Trends in International Mathematics and Science Study data from 46 countries showed that, although the national level of teacher quality in the United States was similar to the international average, the opportunity gap in students' access to qualified teachers between students of high and low socioeconomic status (SES) was among the largest in the world. Cross-national analyses revealed that the countries with better teacher quality produced higher mathematics achievement. However, larger opportunity gaps in access to qualified teachers did not predict larger achievement gaps between high-SES and low-SES students cross-nationally. These analyses provide empirical, cross-national evidence of the importance of investing in teacher quality for improving national achievement. National policies and practices related to improving teacher quality appear to be a promising area for future research to identify how other countries have achieved both excellence and equity in student achievement.

Keywords: comparative study; teacher quality; TIMSS

mproving teacher quality has been the major focus of educational reforms during the past 50 years, and federal involvement in teacher quality policies has increased over time (Cohen-Vogel, 2005). Both the federal government and independent academic groups (e.g., the National Academies' Study of Teacher Preparation Programs) see teacher quality as the crucial driving force for improving student achievement and thus promoting a nation's economic competitiveness in the global society. In a 2006 annual report on teacher quality, Secretary of Education Margaret Spellings stated:

In order to strengthen our nation's competitiveness in the global marketplace, as well as our security at home, we must be certain that teacher proficiency in mathematics, science, technology, and foreign languages is sufficient to enable America's students to achieve at grade level and above in these subjects. (U.S. Department of Education, 2006b, p. iii)

The importance of teacher quality is also noted by the National Academies (2007) in Web information on its Study of Teacher Preparation Programs: "Teacher quality is widely recognized by policymakers, practitioners, and researchers alike to be the most powerful school-related influence on a child's academic performance."

Educational Researcher, Vol. 36, No. 7, pp. 369-387

DOI: $10.3102 / 0013189 \times 07308739$

(C) 2007 AERA. http://er.aera.net
The dominant assumption in U.S. national education policy circles is that our country's teaching workforce is of low quality and that raising certification standards will improve teaching quality, national achievement, and economic competitiveness. Comparatively, there is considerable evidence that mathematics and science instruction in the United States is problematic. Ma (1999) argues that U.S. teachers have a weak grasp of basic mathematical concepts as compared with their Chinese counterparts. Studies of Japan and the United States also have found a significant variation in national patterns of teaching, which have been styled as a "teaching gap" and linked to poor student performance (Stigler \& Hiebert, 1999; Stigler \& Stevenson, 1991). Although most nations do not have such clear ideal types as Japan, analysis of the classroom video data in the 1999 Trends in International Mathematics and Science Study (TIMSS) suggests that these patterns may have more to do with the sequencing and timing of lesson events than with distinct ideal types (Givvin, Hiebert, Jacobs, Hollingsworth, \& Gallimore, 2005, p. 342). Desimone, Smith, Baker, and Ueno (2005) found little variation in "gross teaching patterns" across 38 nations, based on a teacher survey, but did find that U.S. teachers used "conceptual instruction more with high- than with low-performing students" (pp. 523-524).

Whether certification and standard setting will improve teacher quality is a more complicated issue. U.S. studies such as those by Borman and Kimball (2005) and Rivkin, Hanushek, and Kain (2005) suggest that teacher quality is a significant factor in predicting student achievement; however, constructing measures of teacher quality is a challenging task because of the lack of consensus on what constitutes a qualified teacher. Much of the emphasis in crossnational research in mathematics and science has been on improving measures of students' opportunity to learn (see Floden, 2002) and not on studying differences in teacher qualifications. The ongoing enactment of federal and state policies on teacher certification and the use of references to global conditions to justify this emphasis suggest that U.S. policy makers are "trapped" (see LeTendre, Baker, Akiba, \& Wiseman, 2001) by a rhetoric of change and have failed to exploit potential sources of international data that could better inform policy decisions.

A major obstacle in federal and state efforts to increase the quality of the teaching workforce and student achievement is the persistent opportunity gap between students in their access to qualified teachers. High-poverty students and ethnic minority students are twice as likely as low-poverty and majority students to be assigned novice teachers who are new to the profession (Ascher \& Fruchter, 2001; National Center for Education 
Statistics, 2000; Peske \& Haycock, 2006). In addition, they are often taught by uncertified teachers (Ascher \& Fruchter, 2001; Darling-Hammond, 2004; Shen, Mansberger, \& Yang, 2004), out-of-field teachers (those without a major in the subject they teach; Ingersoll, 1999, 2002; Jerald \& Ingersoll, 2002), or teachers with low ACT or SAT scores (Shen et al., 2004). Furthermore, the opportunity gap with regard to student access to teachers with a subject major has widened in recent years (Jerald \& Ingersoll, 2002). Schools in poor and minority areas also experience far more instability in the teacher workforce (Ingersoll, 2002). Inequities in access to qualified teachers are likely to play a significant role in the long-lasting achievement gap in the United States (Darling-Hammond, 2006).

In this cross-national study, we focus on the measurable characteristics of teacher quality that share a relatively common meaning across various cultural contexts: (a) full certification, (b) mathematics major, (c) mathematics education major, and (d) teaching experience of 3 or more years. These characteristics also align with the requirements for teacher quality in the No Child Left Behind Act (NCLB); thus, an examination of these teacher quality indicators in international contexts will greatly inform U.S. policy makers.

We used the TIMSS data collected during 2003 from 46 countries (or, in a few cases, regions or populations within countries; for convenience, in this article we refer to all of them as countries) ${ }^{1}$ to assess national levels of teacher quality and the opportunity gap in access to qualified teachers between students of high and low socioeconomic status (SES). We set out to answer the following research questions:

1. How does the percentage of eighth graders taught by qualified mathematics teachers in the United States differ from that in other countries?

2. How does the level of opportunity gap between high-SES and low-SES students in their access to qualified mathematics teachers in the United States differ from that in other countries?

3. How are the national levels of teacher quality and the opportunity gap associated with national mathematics achievement and the SES-based achievement gap?

\section{Background}

\section{Educational Quality, Inequality, and National Achievement}

Unequal access to high-quality teachers is, of course, part of a larger question of differential access to education based on socioeconomic, racial, or other background attributes. Studies that attempt to compare the relative meritocracy of access of U.S. education have produced mixed results. One of the most recent attempts, the Innocenti Center's Report Card 7 (United Nations Children's Fund [UNICEF], 2007, p. 18), rates the educational well-being of U.S. children below the average of Organisation for Economic Cooperation and Development (OECD) countries. Not only do U.S. students fail to achieve the same mean mathematics scores as their OECD peers, but they also lag in reading and science.

U.S. students appear to be at greater risk of failing to complete school than their OECD peers. Despite the rigidity of the German tracking system (UNICEF, 2002, p. 16; LeTendre,
Hofer, \& Shimizu, 2003, p. 49), roughly $75 \%$ of U.S. 15 - to 19 year-olds are enrolled in full- or part-time education, as compared with nearly $90 \%$ of Germans (UNICEF, 2007, p. 20). The United States has one of the lowest rates of school retention in the developed world. In the same report, the authors note the high rate of child poverty in the United States (p. 29). When using a cross-national standard (percentage of children in households with income less than $50 \%$ of the national median), roughly $22 \%$ of U.S. children live in poverty compared with just over $15 \%$ in the United Kingdom (the next highest OECD country) and about 2\% in Denmark. This high level of childhood poverty, combined with the lack of a strong national system of early childhood education and care, may intensify the significance of opportunity gaps in access to qualified teachers later in the school career.

In a previous analysis of the TIMSS 1999 data, Baker, LeTendre, and Goesling (2005, p. 78) estimated that the United States came in just below the international mean in overall basic school resource inequality. Analysis of family background data from the Program for International Student Assessment (UNICEF, 2002; HampdenThompson \& Johnston, 2006) suggests that the impact of disadvantaged social backgrounds (as measured by parental education, books in the home, immigrant status, and language spoken at home) in the United States is similar to that in other nations. However, Hampden-Thompson and Johnston (2006, p. 11) note that the achievement gap between students from two-parent homes and non-two-parent homes in the United States was significantly higher than the international average.

Both a family's and a community's lack of resources have been identified as significant factors in U.S. educational achievement cross-nationally. This research highlights the importance of access to quality public education as one of the few mechanisms available in the United States to counterbalance the transmission of social status and privilege. Access to high-quality teachers, then, appears essential to mitigating long-term social inequality in the absence of other policy levers. Unlike other nations with more developed social welfare or youth ministries, the United States traditionally has relied on school-based measures to ameliorate the effects of poverty (see the analyses of Head Start programs and Title I in Hacsi, 2002, and Stein, 2004).

\section{Teacher Quality and Student Achievement in the United States}

NCLB requires that all teachers in core academic subjects be highly qualified by the 2005-2006 school year. Highly qualified is defined as fully certified, possessing a bachelor's degree, and demonstrating competence in subject knowledge and teaching. Many states still face difficulties in fully meeting these requirements (U.S. Department of Education, 2006a), and data from the Council of Chief State School Officers (Blank, 2003, p. 6) show large state differences in the numbers of certified teachers providing instruction in subjects such as mathematics. As of 2005, 44 states required a passing score in content-related tests for certification, and 39 states required a content-specific bachelor's degree for at least one of their initial certificates (U.S. Department of Education, 2006b). Although in 2006 the overall teacher pass rate for the content-related test was reported to be $95 \%$, the minimum passing scores are generally lower than the 
national median scores for these tests, indicating a lower contentknowledge requirement for teacher candidates (U.S. Department of Education, 2006b).

In the United States, many empirical studies have been conducted to identify the characteristics of teacher quality that are associated with higher student achievement. Several syntheses of these studies have identified teacher certification, subject matter knowledge, pedagogical knowledge, and teaching experience as significantly associated with higher student achievement or greater achievement gains (Darling-Hammond \& Youngs, 2002; Rice, 2003; Wayne \& Youngs, 2003; Wilson, Floden, \& Ferrini-Mundy, 2001, 2002).

Studies have found that students taught by teachers holding subject-specific certification achieve better. Based on a pairedcomparison design of 36 secondary teachers and 826 students, Hawk, Coble, and Swanson (1985) found that students taught by teachers certified in mathematics scored higher in both general mathematics and algebra than did students taught by teachers certified in other subjects. Goldhaber and Brewer (1997, 2000) analyzed the nationally representative group of secondary school mathematics teachers in the National Education Longitudinal Study of 1988 (NELS:88) data set and found that students had higher achievement gains when their teachers were certified in mathematics as compared with students whose teachers had no certification or certification in other subjects. DarlingHammond (2000) conducted a state-level analysis using the National Assessment of Educational Progress data set and found that the percentage of teachers with full certification and the percentage of teachers with a subject major predicted higher statelevel student achievement in both mathematics and reading.

Contrary to these studies, Rowan, Correnti, and Miller (2002) found that subject-specific certification had no significant impact on elementary school students' achievement growth in mathematics or reading, based on an analysis of survey data from Prospects: The Congressionally Mandated Study of Educational Growth and Opportunity, 1991-1994. These empirical studies seem to suggest that teacher certification matters in secondary schools but not in elementary schools (see Rice, 2003, for the same conclusion).

Subject matter knowledge and pedagogical knowledge have been measured by various indicators: subject major, number of courses taken, and National Teachers Examination (NTE) scores. Goldhaber and Brewer $(1997,2000)$, using NELS:88 data, examined the impact of subject major or degree on student achievement gains among 10th and 12th graders and found that those students who were taught mathematics by teachers with an undergraduate or graduate mathematics major made greater achievement gains than those who were taught mathematics by teachers with a nonmath major or degree (see also Rowan, Chiang, \& Miller, 1997).

The relationship between student achievement and the number of subject matter courses teachers have taken was established by empirical studies in secondary school mathematics (Monk \& King, 1994 ) and secondary school science (Druva \& Anderson, 1983) but not in elementary mathematics (Eberts \& Stone, 1984). The studies that examined the impacts of both subject matter courses and pedagogy courses, however, showed that pedagogy course work had a larger impact on teaching performance (Ferguson \& Womack, 1993) and student achievement in high school mathematics and science (Monk, 1994) than did subject matter course work.
Researchers also used the NTE scores to measure subject matter knowledge and examined how the scores are associated with student achievement. Strauss and Sawyer (1986) analyzed district-level data from one state and found that a $1 \%$ increase in district average NTE scores predicted a 5\% decline in the rate of student failure on mathematics and reading high school competency examinations. The other empirical studies showed a negative or no significant relationship between NTE scores and student achievement in secondary school subjects (Lawrenz, 1975; Summers \& Wolfe, 1977) and in elementary school subjects (Sheehan \& Marcus, 1978). These mixed findings seem to have resulted from differences in the units of analysis (district vs. student). All of these studies were published more than 20 years ago, and new evidence on the relationship between teacher performance on standardized exams and student achievement is needed.

Another indicator of teacher quality is teacher experience. If teacher learning accumulates with longer years of teaching practice, experienced teachers should be more effective than novice teachers in improving student achievement. Many empirical studies have indeed shown a significant and positive relationship between number of years and student achievement (see reviews by Greenwald, Hedges, \& Laine, 1996; Rice, 2003). However, the relationship is not linear. Teachers' effectiveness in improving student achievement appears to increase most in the first 3 years of teaching, but no major improvement in their effectiveness was observed after 3 years of teaching experience (Boyd, Grossman, Lankford, Loeb, \& Wyckoff, 2006; Rice, 2003; Rivkin, Hanushek, \& Kain, 2005). ${ }^{2}$

\section{Teacher Quality Around the World}

Globally, the United States appears to be one of many countries instituting higher standards and certifications for teachers (see Steiner-Khamsi, 2004). In the United States, the focus on certification has been informed by research on out-of-field teaching (Ingersoll, 1999, 2001) ${ }^{3}$ and by comparative and international studies that identified the weaknesses in instructional practices and environments surrounding U.S. teachers in comparison with those of teachers in high-achieving countries (Ginsburg, Cooke, Leinwand, Noell, \& Pollock, 2005; Hiebert et al., 2005; LeTendre, Baker, Akiba, Goesling, \& Wiseman, 2001; Stigler \& Hiebert, 1999; Stigler \& Stevenson, 1991).

Education policy makers around the world have paid attention to teacher quality as a major vehicle to improve student learning (OECD, 2004, 2005; UNESCO Institute for Statistics, 2006). Attracting competent candidates for the teaching profession, retaining highly qualified teachers by providing support and incentives, and ensuring students' access to high-quality teaching have been major focuses of educational reforms in many countries (OCED, 2005). According to a study of 25 countries conducted during 2002-2004 (OCED, 2005), policy makers in the majority of those countries were struggling with the problems resulting from a lack of highly qualified teachers, especially in science- and math-related subjects; the low social status and salary of teachers and their poor working conditions; a lack of systemic induction programs; and inequitable distribution of qualified teachers between high-poverty and low-poverty schools. UNESCO also reports a severe teacher shortage in sub-Saharan African countries, the Arab States, and South Asian countries (UNESCO Institute for Statistics, 2006). 
Many countries around the world share the same concerns with U.S. policy makers and educators about teacher quality.

Some studies have identified significant variations in student access to qualified teachers in other countries. The UNESCO Institute for Statistics (2006) examined the gap in teacher quality among isolated/rural areas, small towns, and large cities in 13 southern and eastern African countries, including South Africa, Botswana, Kenya, and Uganda. A higher percentage of students in isolated/rural areas were taught by teachers with less than 3 years of experience than were students in small towns or large cities in most of these countries. In addition, in Namibia, Tanzania, and Uganda, teachers in isolated/rural schools scored lower in a sixth-grade mathematics test than the teachers in large city schools.

Few studies have examined teachers' characteristics associated with higher student achievement or achievement gain in other countries. However, indicators of teacher quality, the nature of instruction, and teacher policy have been compared between the United States and other countries. Studies have shown that mathematics teachers in high-achieving countries tend to demonstrate balanced attention to challenging content, procedural skills, and conceptual understanding, whereas U.S. teachers' instructional practice is characterized by its focus on lower level mathematics skills (Hiebert et al., 2005; Stigler \& Hiebert, 1999). A comparative study on teachers' work further revealed that U.S. mathematics teachers are assigned to teach multiple subjects and multiple grade levels more often than are Japanese mathematics teachers, who usually teach only mathematics to only one grade level (LeTendre, Baker, Akiba, Goesling, et al., 2001).

A study conducted by the Educational Testing Service compared the United States with high-achieving countries-Australia, England, Hong Kong, Japan, Korea, the Netherlands, and Singapore-in eighth-grade mathematics and science teacher education and development policies (Wang, Coleman, Coley, \& Phelps, 2003). The study found that all the countries except the United States and Australia had centralized systems of teacher education and certification with tighter regulatory control by the central government. All of the compared countries had screening criteria at multiple time points - entry to teacher education program, evaluation of field experience, exit from teacher education program, or certification — whereas in the United States, teacher licensure testing was the only major high-stakes criterion for determining who could become a teacher. Furthermore, teacher induction for new teachers was required in England, Singapore, Japan, and Australia; in the United States, induction programs were fragmented because of variations in policies and resources available.

In summary, the empirical studies that link teacher quality and student achievement are limited to the U.S. research literature. Existing comparative studies have examined teacher quality using various indicators (i.e., instruction, working conditions, and teacher education policy), yet none of them has cross-nationally examined how national levels of teacher quality are associated with national achievement. Moreover, although an opportunity gap in student access to qualified teachers has been identified in the United States and other countries, little is known about how the gap leads to inequality in learning outcomes across students with various backgrounds. The present study uses nationally representative data collected from 46 countries around the world to examine this question. By studying the links between teacher quality, opportunity gaps, national achievement, and achievement gaps from a global perspective, we attempt to provide empirical findings to inform U.S. federal and state policy making on teacher quality.

\section{Method}

\section{Measuring Teacher Quality}

Measuring teacher quality across various national contexts poses methodological challenges. Each country defines qualified teacher differently. Many comparative studies have shown that the cultural roles and identities of teachers vary across countries (Anderson-Levitt, 2001; LeTendre, 1994, 1995; Shimahara \& Sakai, 1995; Welmond, 2002). National patterns of school organization and political priorities also affect teachers' work roles and approaches to teaching (LeTendre, Baker, Akiba, Goesling, et al. 2001; Osborn et al., 2003, p. 98).

However, the past century has witnessed considerable homogenization of curricula within core subject areas in national curricula (Benavot \& Braslavsky, 2006; Benavot, Cha, Kamens, Meyer, \& Wong, 1991). Work by neoinstitutionalist scholars (Meyer, Ramirez, \& Soysal, 1992; Ramirez \& Boli, 1987) shows a longterm, transnational trend toward isomorphism in core curriculum and basic instructional practices. Although scholars continue to debate the extent to which teaching is affected by national cultures or a global cultural dynamic (see Anderson-Levitt, 2005; Givvin et al., 2005; LeTendre, Baker, Akiba, Goesling, et al., 2001), it is clear that for highly structured subjects such as mathematics, teachers around the world can readily recognize (and critique) core curricular concepts and instructional strategies across a wide range of nations (Stigler \& Hiebert, 1999).

In this study, we decided to use measurable characteristics of teacher quality that have been linked with student achievement in past studies and that share a relatively common meaning across various cultural contexts: (a) full certification, (b) mathematics major, (c) mathematics education major, and (d) teaching experience of 3 or more years.

In addition to these four separate measures of teacher quality, we developed an overall measure of teacher quality based on percentage of students taught by mathematics teachers who are fully certified, who majored in mathematics or mathematics education, and who have 3 or more years of teaching experience. This overall teacher quality measure allows us to examine the cumulative impact of multiple aspects of teacher quality in addition to the impact of each characteristic. We also measure mathematics major and mathematics education major separately, unlike most existing studies, to differentiate the impact of teacher learning through mathematics courses only from the impact of teacher learning through both mathematics and mathematics education courses (Wayne \& Youngs, 2003).

Wang et al. (2003) found that although the number of requirements for teachers varied across the eight countries they examinedAustralia, England, Hong Kong, Japan, Korea, the Netherlands, Singapore, and the United States - the structure and content of undergraduate teacher education programs were similar across those countries, including courses in subject content and pedagogy and field experiences observing and teaching students. Similarly, Osborn et al. (2003) found that the training of teachers in France, England, and Denmark was similar in "length, structure, context and level of 
training" (p. 74). Issues of comparability in preservice teacher certification measures have been systematically addressed in previous OECD studies (see Siniscalco, 2002, p. 47). Thus, the definitions of these four measures - full certification, mathematics major, mathematics education major, and teaching experience of 3 or more years - are similar enough across these countries to allow crossnational comparison and analyses. (For details on the development of the TIMSS teacher questionnaire, see Martin, Mullis, \& Chrostowski, 2004, especially chap. 3.)

It is also important, however, to be aware of the possible differences across countries in interpreting data from international comparisons. The data are based on teachers' self-reports, and teachers in each country interpret the questions based on their understandings of the four measures. Thus, when we present the percentage of students taught by certified teachers, we need to keep in mind that it is the percentage of students taught by teachers who met the certification criteria in each country. The same interpretation applies to mathematics major and mathematics education major. Although the criteria tend to be similar in format, other factors differentiate the quality of teachers across countries, such as quality and difficulty of courses required for certification, major field of study, and qualification of teacher educators. Understanding both the similarities and the differences is essential if cross-national comparisons are to have beneficial effects on important policy decisions.

\section{Data}

The TIMSS was developed by the International Association for the Evaluation of Educational Achievement (IEA) to measure trends in students' mathematics and science achievement in more than 50 nations around the world. This study focused on data from eighth graders and their mathematics teachers. A two-stage stratified sampling method was used to sample secondary schools first and then eighth-grade classrooms from the sampled schools. The schools were first stratified by type of school, region of the country, type of location, and percentage of minority students. A probabilityproportional-to-size technique was used in the process of selecting schools to give a higher probability of selection to larger schools. ${ }^{4}$ One or two mathematics classrooms were chosen with an equal probability of selection within the sampled schools based on the list of eighth-grade classrooms. The mathematics teachers of these classrooms were selected, and they filled out a teacher questionnaire. The 2003 data collected from eighth graders and their mathematics teachers in 46 countries with at least one measure of teacher quality were analyzed in this study. The sample sizes of eighth graders and eighth-grade teachers from which the national variables were developed ranged from 2,830 in England to 8,912 in the United States for students and from 72 in Morocco to 377 in the United States for teachers.

\section{Measures}

We measured teacher quality by the percentages of students taught by (a) teachers with full certification; (b) teachers with a mathematics major; (c) teachers with a mathematics education major; (d) teachers with 3 or more years of teaching experience; and (e) teachers with full certification, a mathematics or mathematics education major, and 3 or more years of teaching experience (overall measure of teacher quality).
Regarding certification, mathematics teachers of eighth graders were asked, "What type of license or certificate do you hold?" with the answer choices of "full certificate," "provisional certificate," "emergency certificate," and "other." Their responses were recoded as follows: $1=$ full certificate, $0=$ any of the others. Regarding mathematics major and mathematics education major, teachers were asked, "During your postsecondary education, was 'mathematics' your major or main area(s) of study?" and "During your postsecondary education, was 'mathematics education' your major or main area(s) of study?" The teachers responded yes (coded as 1 ) or no (coded as 0 ) to each question. Regarding teaching experience, mathematics teachers were asked, "By the end of this school year, how many years will you have been teaching altogether?" and the teachers reported the number of years. Their responses were recoded as follows: $0=$ none to 2 years, $1=3$ or more years. Descriptive statistics of these teacher-level data are presented in Appendix A.

Because we will examine the relationship between teacher quality and student achievement outcomes, we measure nationallevel teacher quality by the percentage of students who were taught by qualified teachers rather than by the percentage of qualified teachers within each nation. Therefore, all of the teacherlevel data were disaggregated at the student level after being merged with the data of the eighth graders who were taught by these mathematics teachers. Descriptive statistics of these variables are presented in Appendix B.

To measure the national-level opportunity gap, we developed five variables based on the difference between the percentage of high-SES students (standard deviation of 1 or higher) and the percentage of low-SES students (standard deviation of -1 or lower) who were taught by qualified teachers based on the five teacher quality variables. ${ }^{5}$

For student achievement measures, we developed two national-level variables: (a) the national mean mathematics achievement of eighth graders and (b) the achievement gap measured by the difference in the mean mathematics score between high-SES students (standard deviation of 1 or higher) and lowSES students (standard deviation of -1 or lower). National mean achievement is the overall national level of student learning; the achievement gap is the inequality in learning outcomes by SES. It is important to consider both of these variables because a country may produce a high average mathematics score in spite of large disparities in the mathematics scores of high-SES and low-SES students. Both measures are important for nations that attempt to achieve excellence and equity in student achievement.

Two national economic indicators were analyzed as control variables for the examination of the relationships between (a) teacher quality and national achievement and (b) opportunity gap and achievement gap. Educational expenditure as percentage of gross domestic product (GDP) — a measure of educational investment-and GDP per capita are significant predictors of national achievement (Baker, Goesling, \& LeTendre, 2002; Schmidt et al., 2001, pp. 314-320). Educational enrollment ratio as a measure of educational development was also collected but was excluded from the analysis because of its high correlation with GDP per capita (Pearson correlation $=.71$, significant). These indicators were collected from the UNESCO Institute for Statistics (1998-2006). ${ }^{6}$ 


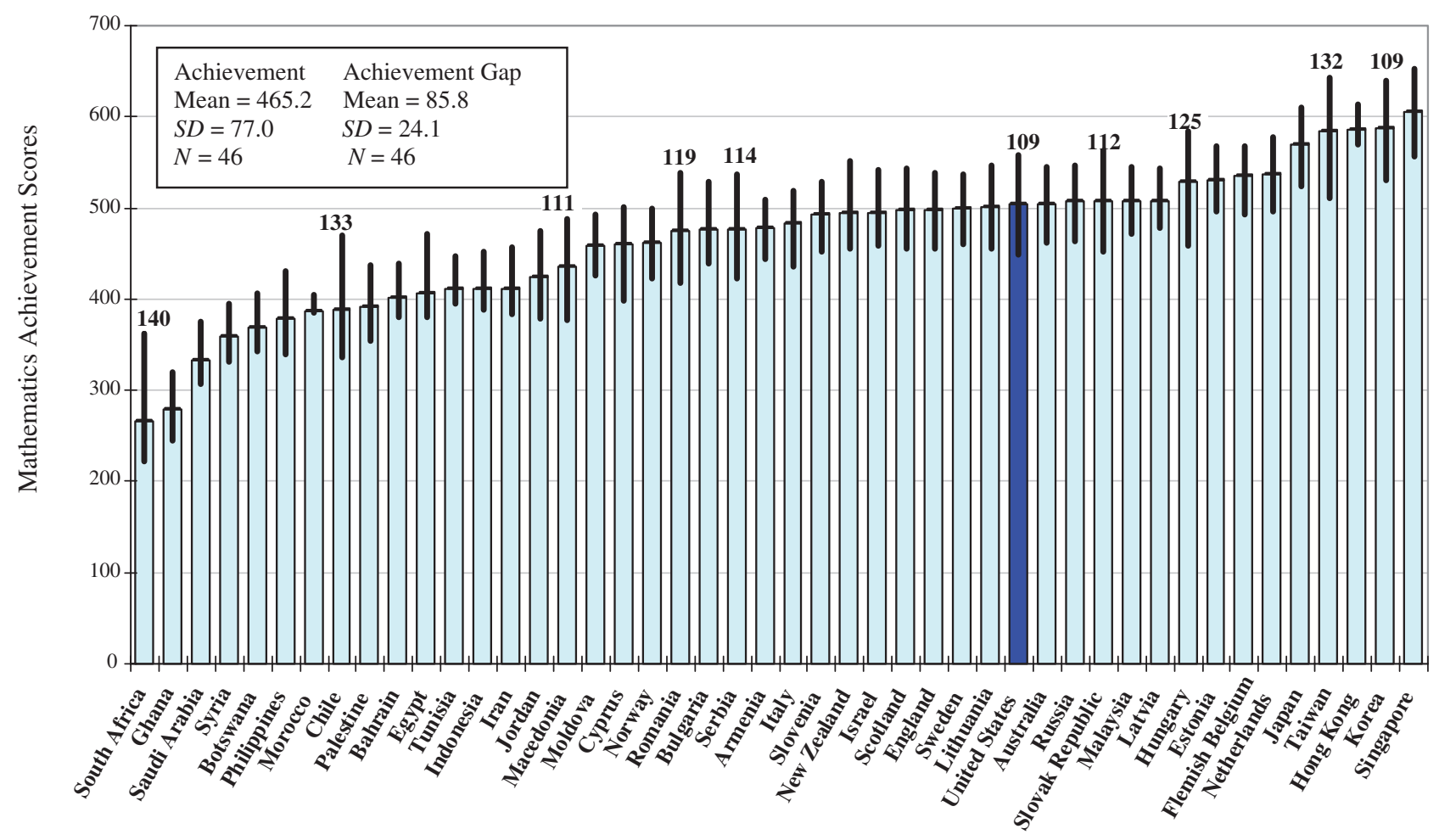

FIGURE 1. Comparison of mathematics achievement scores and achievement gap in 46 countries in 2003. The line attached to each bar represents the size of the achievement gap measured by the difference in mean achievement between students of high and low socioeconomic status. The 10 countries with the largest achievement gaps have numbers above their bars showing the size of the gaps. All the data are from the 2003 Trends in International Mathematics and Science Study (TIMSS) mathematics assessment.

\section{Analysis}

To investigate our first research question (How does the percentage of eighth graders taught by qualified mathematics teachers in the United States differ from that in other countries?), we created the percentage rankings from the highest to the lowest for each of the teacher quality indicators: full certification, mathematics major, mathematics education major, teaching experience of 3 or more years, and overall teacher quality. In addition, the difference in the percentage of highSES students and low-SES students who are taught by qualified teachers was computed to assess the size of opportunity gap, and the countries were ranked from highest to lowest based on the gap. Thus, we addressed the second research question (How does the level of opportunity gap between high-SES and low-SES students in their access to qualified mathematics teachers in the United States differ from that in other countries?). To approach the final research question (How are the national levels of teacher quality and the opportunity gap associated with national mathematics achievement and the SES-based achievement gap?), we first conducted correlation analyses at the national level to examine the relationship between teacher quality/opportunity gap and national mean mathematics achievement/SES-based achievement gap. Then, we conducted multiple regression analyses to include two national-level control variables: educational expenditure as percentage of GDP and GDP per capita.

\section{Results}

\section{National Achievement and Achievement Gap in Eighth-Grade Mathematics}

The magnitude of the achievement gap between wealthy and poor students around the world has been examined by a few studies, and the findings have been inconsistent. Baker et al. (2005) showed that disadvantaged 12th graders (students with mothers having less than a high school education and from single-parent homes) in the United States achieved the lowest compared with those in nine other developed countries, but Hampden-Thompson and Johnson (2006) found that the achievement gap in the United States based on SES characteristics (parents' education level, parents' occupational status, and number of books at home) and family characteristics (students' language at home, immigrant status, and single-parent family) is no different from the international average of 20 developed countries.

There is a need to understand the level of achievement gap using a larger number of comparison countries with various economic levels. Figure 1 presents the national mean mathematics achievement of eighth graders in 46 countries, with the size of achievement gap represented in the vertical lines attached to the bar graphs in 46 countries based on 2003 TIMSS data. The United States is highlighted in the graph, and 10 countries with the highest achievement gap are indicated, with the size of the gap attached to the vertical lines. Among 46 countries, the United States is ranked 15th in national achievement and 10th in the size of achievement gap. National achievement scores varied from 266 in South Africa to 605 in Singapore; U.S. eighth graders scored 504 on average, higher than the international average of 465.2 .

Although U.S. eighth graders' achievement was higher than the international average, the SES-based achievement gap was larger than in many other countries. Morocco showed the smallest achievement gap (19) and South Africa showed the largest (140). These numbers represent the differences in mean mathematics scores between high-SES students and low-SES students. 
In the United States, the achievement gap between high-SES and low-SES students was 109, higher than the cross-national average of 85.8 .

We can see from the figure that both high-achieving countries such as Korea and Taiwan and low-achieving countries such as Chile and South Africa produce large achievement gaps between high-SES and low-SES students. The correlation coefficient of the relationship between national achievement and achievement gap was .11 and not statistically significant. The data show that high-achieving countries do not necessarily produce a smaller achievement gap between high- and low-SES students.

\section{National Level of Teacher Quality}

How does the level of teacher quality in the United States compare with that in other countries? Table 1 shows the percentage ranking from highest to the lowest for each of the five teacher quality indicators. In the United States, $95.4 \%$ of eighth graders are taught by fully certified teachers, which is higher than the international average of $91.2 \%$. In 11 out of 39 countries, every student surveyed was taught by a fully certified teacher, in comparison with only $49.7 \%$ of students in South Africa and 25.9\% of students in Macedonia. In these 11 countries, it is likely that strict government regulations prevent teachers from entering the teaching profession without full certification, although the requirements for full certification may differ across countries.

When we look at mathematics major, only $47.3 \%$ of U.S. students are taught mathematics by teachers with a mathematics major, a significantly smaller percentage than the international mean of $70.9 \%$. The United States ranked 41 among 46 countries in this indicator of teacher quality. The data suggest that, in a majority of countries, unlike in the United States, possession of a mathematics degree is a common characteristic of teachers teaching mathematics to eighth graders. Cross-nationally, the percentage varies from only $20.8 \%$ in Italy to $98.1 \%$ in Latvia.

A higher percentage of eighth graders are taught by teachers with a mathematics education major who received both subject content and pedagogical preparation for teachers to teach mathematics. The data show that $55.3 \%$ of U.S. eighth graders are taught by teachers with a mathematics education major. The cross-national average is $53.7 \%$, which indicates that having a mathematics education major is less common among teachers teaching mathematics than having a mathematics major in many countries. Here we see extreme cross-national variation: The percentage varies from $2.8 \%$ in Norway to $92.2 \%$ in Hungary.

Appendix B shows the breakdown of the percentages by mathematics major, mathematics education major, both mathematics and mathematics education major, and no math-related major. In the United States, $19.1 \%$ of students are taught by teachers with mathematics major only, 27.1 of students are taught by teachers with mathematics education major only, and $28.2 \%$ of students are taught by teachers with both mathematics major and mathematics education major.

The figures in the United States indicate that a significant proportion of U.S. eighth graders are taught mathematics by teachers without subject-specific training. Appendix A shows that in the United States $29.7 \%$ of teachers are teaching mathematics without a major in mathematics or mathematics education. Appendix B shows that $25.6 \%$ of students are taught by these teachers. These figures are similar to previous studies conducted by Ingersoll (1999), which found that 33\% of secondary mathematics teachers do not have a major or minor in a math-related field, and by Seastrom, Gruber, Henke, McGrath, and Cohen (2002), which showed that $23 \%$ of middle school students were being taught by mathematics teachers who had neither majored in nor had a certificate to teach mathematics. These data confirm that more than 1 eighth grader in every 4 is taught by an out-offield teacher in the United States, which is a significantly higher proportion than the international average of $13.2 \%$.

Teaching experience is another indicator of teacher quality associated with higher student achievement in the United States; $90.8 \%$ of U.S. eighth graders are taught by teachers with 3 or more years of teaching experience, a figure almost identical to the international average of $90.7 \%$. Cross-nationally, only a small percentage of eighth graders are taught by novice teachers with less than 3 years of experience, but there was some variation, ranging from $71.6 \%$ in Ghana to $100 \%$ in Armenia and Latvia. ${ }^{7}$

When we consider teacher quality, it is also important that we measure multiple aspects to holistically understand the nature of teacher quality. Cross-nationally, $62.3 \%$ of eighth graders are taught by teachers with all of these qualifications, and it ranged from only $7.4 \%$ in Macedonia to $93.5 \%$ in Lithuania. The figure in the United States is approximately the same as the crossnational average; $60.3 \%$ of U.S. eighth graders are taught mathematics by teachers with full certification, mathematics or mathematics education major, and at least 3 years of teaching experience. However, if we consider that these characteristics are minimal requirements for qualified teachers, a lack of access to these teachers by $40 \%$ of U.S. eighth graders requires major policy attention.

\section{National Level of Opportunity Gap in the Access to Qualified Teachers}

How does access to qualified teachers vary by students' SES? Table 2 presents the difference in the percentage of high-SES students and low-SES students who are taught by qualified teachers. For the countries with a positive value of the percentage difference, high-SES students have a greater opportunity to be taught by qualified teachers than do low-SES students, indicating the existence of unequal access to qualified teachers and a greater opportunity gap. For the countries with a negative value for the percentage difference, low-SES students are more likely to be taught by qualified teachers than are high-SES students, indicating the existence of needs-based access to qualified teachers and a smaller opportunity gap. ${ }^{8}$

When we look at the international average across 46 countries, the opportunity gap is no more than $3 \%$ for all indicators of teacher quality. On average, many countries are successful in equalizing access to qualified teachers along the line of SES and also providing low-SES students a higher level of access to qualified teachers compared with high-SES students. However, we can also observe major variations across the countries in the size of opportunity gap in the access to qualified teachers.

For students' access to fully certified teachers, the percentage gap varied from -13.2 in Iran to 17.5 in South Africa. In Iran, low-SES students had greater access to fully certified teachers than did high-SES students, whereas in South Africa, high-SES 
Table 1

National Level of Teacher Quality: Percentage of Students Taught by Qualified Teachers

\begin{tabular}{|c|c|c|c|c|c|c|c|c|c|c|c|c|c|c|}
\hline & $\begin{array}{c}\text { Fully } \\
\text { Certified } \\
\text { Teachers }^{\mathrm{a}}\end{array}$ & $\%$ & & $\begin{array}{c}\text { Teachers } \\
\text { With Math } \\
\text { Major }\end{array}$ & $\%$ & & $\begin{array}{c}\text { Teachers } \\
\text { With Math } \\
\text { Education Major }\end{array}$ & $\%$ & & $\begin{array}{c}\text { Teachers With } \\
3 \text { or More } \\
\text { Years of Teaching } \\
\text { Experience }\end{array}$ & $\%$ & & $\begin{array}{l}\text { Overall } \\
\text { Teacher } \\
\text { Quality }\end{array}$ & $\%$ \\
\hline 1 & Armenia & 100.0 & 1 & Latvia & 98.1 & 1 & Hungary & 92.2 & 1 & Armenia & 100.0 & 1 & Lithuania & 93.5 \\
\hline 1 & Botswana & 100.0 & 2 & Cyprus & 97.7 & 2 & Bahrain & 89.2 & 1 & Latvia & 100.0 & 2 & Egypt & 87.3 \\
\hline 1 & Bulgaria & 100.0 & 3 & Bulgaria & 96.6 & 3 & Latvia & 85.4 & 3 & Egypt & 99.1 & 3 & Slovenia & 87.2 \\
\hline 1 & Indonesia & 100.0 & 4 & Romania & 96.5 & 4 & Bulgaria & 81.6 & 4 & Russia & 98.3 & 4 & Romania & 85.9 \\
\hline 1 & Italy & 100.0 & 5 & Flemish Belgium & 95.9 & 5 & Indonesia & 80.6 & 5 & Moldova & 97.9 & 5 & Russia & 85.7 \\
\hline 1 & Lithuania & 100.0 & 6 & Russia & 95.6 & 6 & Egypt & 79.7 & 6 & Bulgaria & 97.8 & 6 & Bulgaria & 84.9 \\
\hline 1 & Morocco & 100.0 & 6 & Serbia & 95.6 & 7 & Slovenia & 72.0 & 6 & Lithuania & 97.8 & 7 & Serbia & 84.6 \\
\hline 1 & Norway & 100.0 & 8 & Saudi Arabia & 93.3 & 8 & Syria & 71.3 & 8 & Chile & 97.6 & 8 & Korea & 84.1 \\
\hline 1 & Russia & 100.0 & 9 & Lithuania & 92.3 & 9 & Estonia & 67.7 & 9 & Morocco & 96.7 & 9 & Indonesia & 83.1 \\
\hline 1 & Singapore & 100.0 & 10 & Moldova & 87.5 & 10 & Israel & 67.4 & 9 & Romania & 96.7 & 10 & $\begin{array}{l}\text { Slovak } \\
\text { Republic }\end{array}$ & 81.7 \\
\hline 1 & Sweden & 100.0 & 11 & Singapore & 85.7 & 10 & Netherlands & 67.4 & 11 & Hungary & 96.6 & 11 & Israel & 80.5 \\
\hline 12 & Egypt & 99.7 & 12 & Egypt & 85.1 & 12 & Saudi Arabia & 65.8 & 11 & Italy & 96.6 & 12 & Moldova & 79.4 \\
\hline 13 & Japan & 99.3 & 13 & Armenia & 84.6 & 13 & Korea & 64.4 & 13 & Japan & 96.3 & 13 & Estonia & 77.7 \\
\hline 14 & Korea & 99.1 & 14 & Syria & 84.1 & 14 & Taiwan & 62.9 & 14 & Slovenia & 96.1 & 14 & Saudi Arabia & 74.7 \\
\hline 15 & Israel & 98.7 & 15 & Tunisia & 82.7 & 15 & Slovak Republic & 61.3 & 15 & Estonia & 95.8 & 15 & Japan & 73.8 \\
\hline 16 & Taiwan & 98.2 & 16 & Slovenia & 80.9 & 16 & Scotland & 59.7 & 16 & Macedonia & 95.2 & 16 & Taiwan & 70.8 \\
\hline 17 & Jordan & 97.5 & 17 & Japan & 80.7 & 17 & Serbia & 59.6 & 17 & Indonesia & 94.7 & 17 & Armenia & 70.7 \\
\hline 18 & Saudi Arabia & 96.9 & 18 & Estonia & 79.9 & 18 & Australia & 59.0 & 17 & Israel & 94.7 & 18 & Jordan & 66.9 \\
\hline 19 & Romania & 96.5 & 19 & Taiwan & 79.7 & 18 & Sweden & 59.0 & 19 & Iran & 94.2 & 19 & Philippines & 65.3 \\
\hline 20 & Australia & 96.2 & 20 & Iran & 77.8 & 20 & England & 58.0 & 20 & Netherlands & 93.5 & 20 & Botswana & 63.0 \\
\hline 21 & United States & 95.4 & 21 & Botswana & 77.1 & 21 & Japan & 57.6 & 21 & Serbia & 92.9 & 21 & Singapore & 62.6 \\
\hline 22 & Philippines & 94.6 & 22 & Scotland & 75.9 & 22 & Singapore & 56.7 & 22 & Flemish Belgium & 92.3 & 22 & Bahrain & 61.8 \\
\hline 22 & Slovenia & 94.6 & 23 & England & 75.6 & 23 & Hong Kong & 56.2 & 23 & Norway & 92.0 & 22 & Sweden & 61.8 \\
\hline 24 & Estonia & 94.5 & 24 & Israel & 74.6 & 24 & United States & 55.3 & 24 & Korea & 91.5 & 24 & United States & 60.3 \\
\hline 25 & Chile & 93.6 & 25 & Morocco & 73.1 & 25 & Philippines & 53.6 & 25 & Slovak Republic & 91.3 & 25 & Australia & 59.3 \\
\hline 25 & $\begin{array}{l}\text { Slovak } \\
\text { Republic }\end{array}$ & 93.6 & 26 & Jordan & 72.3 & 26 & Ghana & 53.1 & 26 & Australia & 91.1 & 26 & Morocco & 57.8 \\
\hline 27 & Tunisia & 92.8 & 27 & South Africa & 68.1 & 27 & Botswana & 51.2 & 27 & United States & 90.8 & 27 & Iran & 57.6 \\
\hline 28 & Moldova & 91.1 & 28 & Sweden & 66.7 & 28 & Malaysia & 47.9 & 28 & England & 89.7 & 28 & Hong Kong & 56.3 \\
\hline 29 & Serbia & 90.5 & 29 & Philippines & 62.4 & 29 & Armenia & 45.4 & 29 & Scotland & 89.5 & 29 & Chile & 49.9 \\
\hline 30 & Palestine & 90.3 & 30 & Hong Kong & 61.9 & 30 & Moldova & 43.9 & 30 & South Africa & 87.5 & 30 & Syria & 49.4 \\
\hline 31 & Bahrain & 87.4 & 31 & Australia & 61.5 & 31 & Palestine & 42.6 & 31 & Hong Kong & 87.3 & 31 & Malaysia & 47.3 \\
\hline 32 & Malaysia & 86.7 & 32 & Macedonia & 60.0 & 32 & Lithuania & 40.9 & 32 & Bahrain & 87.1 & 32 & Tunisia & 41.6 \\
\hline 33 & Iran & 85.0 & 33 & Slovak Republic & 59.5 & 33 & South Africa & 40.1 & 33 & Philippines & 86.7 & 33 & Palestine & 40.8 \\
\hline 34 & Hong Kong & 81.5 & 34 & Indonesia & 58.8 & 34 & Macedonia & 39.7 & 34 & Jordan & 86.5 & 34 & New Zealand & 35.9 \\
\hline 35 & Ghana & 77.1 & 35 & Ghana & 57.4 & 35 & Tunisia & 38.7 & 34 & Taiwan & 86.5 & 35 & Ghana & 31.9 \\
\hline 36 & New Zealand & 76.8 & 36 & Chile & 52.9 & 36 & Iran & 32.6 & 36 & Cyprus & 85.6 & 36 & Norway & 26.4 \\
\hline 37 & Syria & 72.0 & 37 & Palestine & 51.2 & 37 & Chile & 28.8 & 37 & Malaysia & 85.3 & 37 & South Africa & 25.1 \\
\hline 38 & South Africa & 49.7 & 38 & New Zealand & 49.9 & 38 & Jordan & 28.3 & 38 & Tunisia & 85.0 & 38 & Italy & 17.1 \\
\hline \multirow[t]{10}{*}{39} & Macedonia & 25.9 & 39 & Netherlands & 49.4 & 39 & New Zealand & 24.1 & 39 & New Zealand & 83.7 & 39 & Macedonia & 7.4 \\
\hline & & & 40 & Bahrain & 48.9 & 40 & Romania & 24.0 & 39 & Sweden & 83.7 & & & \\
\hline & & & 41 & United States & 47.3 & 41 & Cyprus & 23.4 & 41 & Palestine & 82.3 & & & \\
\hline & & & 42 & Malaysia & 45.9 & 42 & Morocco & 17.0 & 42 & Saudi Arabia & 81.7 & & & \\
\hline & & & 43 & Hungary & 40.9 & 43 & Norway & 2.8 & 43 & Syria & 79.7 & & & \\
\hline & & & 44 & Korea & 40.4 & & & & 44 & Botswana & 78.4 & & & \\
\hline & & & 45 & Norway & 37.4 & & & & 45 & Singapore & 75.0 & & & \\
\hline & & & 46 & Italy & 20.8 & & & & 46 & Ghana & 71.6 & & & \\
\hline & $M$ & 91.2 & & $M$ & 70.9 & & $M$ & 53.7 & & $M$ & 90.7 & & $M$ & 62.3 \\
\hline & $S D$ & 14.8 & & $S D$ & 19.4 & & $S D$ & 20.2 & & $S D$ & 6.9 & & $S D$ & 21.7 \\
\hline
\end{tabular}

Note. The number before each country name indicates ranking based on the percentage for the teacher quality indicator for that column. Flemish Belgium refers to the Flemish-speaking population in Belgium. Data from the United States are bolded to show where the country stands cross-nationally.

${ }^{a}$ The data on certification were not available from Flemish Belgium, Cyprus, England, Hungary, Latvia, the Netherlands, or Scotland.

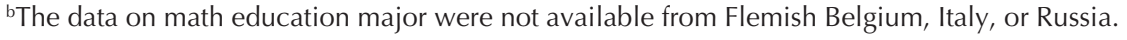


Table 2

National Level of Opportunity Gap: Difference (\%) Between High- and Low-SES Students in Percentage of Students Taught by Qualified Teachers

\begin{tabular}{|c|c|c|c|c|c|c|c|c|c|c|c|c|}
\hline $\begin{array}{c}\text { Fully } \\
\text { Certified } \\
\text { Teachers }^{\mathrm{a}}\end{array}$ & $\%$ & $\begin{array}{c}\text { Teachers } \\
\text { With Math } \\
\text { Major }\end{array}$ & $\%$ & & $\begin{array}{c}\text { Teachers } \\
\text { With Math } \\
\text { Education Major }\end{array}$ & $\%$ & & $\begin{array}{c}\text { Teachers With } \\
3 \text { or More } \\
\text { Years of Teaching } \\
\text { Experience }\end{array}$ & $\%$ & & $\begin{array}{l}\text { Overall } \\
\text { Teacher } \\
\text { Quality }\end{array}$ & $\%$ \\
\hline 1 South Africa & 17.5 & 1 Chile & 24.2 & 1 & Chile & 42.4 & 1 & Syria & 16.6 & 1 & Syria & 18.5 \\
\hline 2 Syria & 16.7 & 2 Netherlands & 23.3 & 2 & Netherlands & 19.2 & 2 & Tunisia & 15.9 & 2 & Chile & 17.1 \\
\hline 3 Hong Kong & 4.3 & 3 New Zealand & 17.8 & 3 & Estonia & 14.3 & 3 & Singapore & 10.5 & 3 & Taiwan & 16.8 \\
\hline 4 Slovenia & 3.2 & 4 England & 17.5 & 4 & United States & 13.8 & 4 & Saudi Arabia & 10.2 & 4 & United States & 14.4 \\
\hline 5 Macedonia & 2.9 & 5 Taiwan & 15.4 & 5 & Syria & 12.7 & 5 & Scotland & 8.9 & 5 & Hong Kong & 12.6 \\
\hline 6 Estonia & 2.6 & 6 United States & 10.0 & 6 & Singapore & 12.1 & 5 & Botswana & 8.9 & 6 & Singapore & 12.2 \\
\hline 7 Romania & 2.5 & 7 Macedonia & 8.8 & 7 & Taiwan & 11.7 & 7 & Palestine & 8.2 & 7 & Jordan & 11.6 \\
\hline 8 Australia & 1.8 & 8 Bahrain & 7.8 & 8 & Botswana & 10.3 & 8 & Iran & 8.1 & 8 & Saudi Arabia & 9.8 \\
\hline 8 United States & 1.8 & 9 Flemish Belgium & 7.4 & 9 & Jordan & 9.7 & 9 & Taiwan & 6.3 & 9 & Romania & 9.3 \\
\hline 10 Moldova & 1.4 & 10 Botswana & 6.6 & 10 & Moldova & 8.4 & 10 & Macedonia & 5.9 & 10 & Australia & 7.0 \\
\hline 11 Serbia & 1.2 & 11 Romania & 6.5 & 11 & Slovenia & 8.1 & 11 & Australia & 5.8 & 11 & Tunisia & 6.2 \\
\hline 12 Japan & 0.9 & 12 Norway & 6.3 & 12 & England & 6.1 & 12 & Flemish Belgium & 5.6 & 12 & Slovenia & 5.8 \\
\hline 13 Palestine & 0.4 & 12 Korea & 6.3 & 12 & Cyprus & 6.1 & 13 & Malaysia & 4.5 & 13 & Indonesia & 4.9 \\
\hline 14 Ghana & 0.1 & 14 Armenia & 4.6 & 14 & Tunisia & 5.7 & 14 & Bahrain & 4.0 & 14 & Macedonia & 4.8 \\
\hline 15 Botswana & 0.0 & 15 Slovenia & 3.9 & 15 & Hungary & 5.0 & 14 & Slovak Republic & 4.0 & 15 & Palestine & 4.5 \\
\hline 15 Norway & 0.0 & 16 Estonia & 3.1 & 16 & Philippines & 4.8 & 16 & Hong Kong & 3.8 & 15 & $\begin{array}{l}\text { Slovak } \\
\text { Republic }\end{array}$ & 4.5 \\
\hline 15 Lithuania & 0.0 & 17 Syria & 2.9 & 17 & Slovak Republic & 4.4 & 17 & England & 3.7 & 15 & South A & 4.5 \\
\hline 15 Sweden & 0.0 & 17 Sweden & 2.9 & 18 & Armenia & 4.2 & 17 & Jordan & 3.7 & 18 & Serbia & 3.4 \\
\hline 15 Singapore & 0.0 & 19 South Africa & 2.5 & 19 & Romania & 4.1 & 19 & United States & 3.6 & 18 & Norv & 3.4 \\
\hline 15 Russia & 0.0 & 19 Egypt & 2.5 & 20 & Indonesia & 3.6 & 20 & Morocco & 3.3 & 20 & Bots & 3.0 \\
\hline 15 Italy & 0.0 & 21 Bulgaria & 2.2 & 21 & South Africa & 2.6 & 21 & Cyprus & 2.0 & 21 & Estonia & 2.6 \\
\hline 15 Indonesia & 0.0 & 22 Serbia & 1.9 & 22 & Sweden & 2.4 & 22 & Italy & 1.8 & 22 & Bulgaria & 1.9 \\
\hline 15 Bulgaria & 0.0 & 23 Singapore & 1.8 & 23 & Israel & 2.3 & 23 & Romar & 1.6 & 22 & Lithuan & 1.9 \\
\hline 15 Morocco & 0.0 & 24 Hungary & 1.4 & 24 & Scotland & 1.4 & 23 & Slovenia & 1.6 & 24 & Japan & 0.9 \\
\hline 15 Armenia & 0.0 & 25 Slovak Republic & 1.3 & 25 & Palestine & -0.3 & 25 & Russia & 1.3 & 25 & Italy & -0.3 \\
\hline 26 Korea & -0.3 & 26 Italy & 1.1 & 26 & Lithuania & -0.9 & 26 & Bulgaria & 1.1 & 26 & Israel & -1.0 \\
\hline 27 Jordan & -0.5 & 27 Iran & 0.1 & 27 & Aus & -1.0 & 27 & Serbia & 0.9 & 27 & Russ & -2.7 \\
\hline 28 Taiwan & -0.8 & 27 Malaysia & 0.1 & 28 & Norway & -1.3 & 27 & Lithuania & 0.9 & 28 & Bahrain & -3.3 \\
\hline 29 Saudi Arabia & -1.2 & 27 Hong Kong & 0.1 & 29 & Egypt & -1.8 & 29 & South Africa & 0.8 & 29 & Sweden & -3.7 \\
\hline 30 Israel & -1.3 & 30 Japan & -0.1 & 30 & Morocco & -2.0 & 30 & Philippines & 0.2 & 30 & Korea & -3.9 \\
\hline 31 Egypt & -1.5 & 31 Russia & -0.5 & 31 & Saudi Arabia & -2.3 & 31 & Armenia & 0.0 & 31 & Armenia & -4.6 \\
\hline $\begin{array}{l}31 \text { Slovak } \\
\text { Republic }\end{array}$ & -1.5 & 32 Indonesia & -0.7 & 32 & Hong Kong & -3.1 & 31 & Latvia & 0.0 & 31 & Egypt & -4.6 \\
\hline 33 Tunisia & -1.7 & 32 Scotland & -0.7 & 33 & & -3.5 & 33 & & -0.5 & 33 & Philippines & -4.9 \\
\hline 34 Philippines & -2.3 & 34 Saudi Arabia & -0.9 & 34 & Bahrain & -3.9 & 34 & Ghana & -0.9 & 34 & Iran & -5.2 \\
\hline 35 Bahrain & -6.3 & 35 Australia & -1.0 & 35 & Ghana & -4.7 & 35 & Indonesia & -1.2 & 35 & Morocco & -8.8 \\
\hline 36 New Zealand & -10.7 & 36 Jordan & -1.1 & 36 & Latvia & -4.9 & 36 & Egypt & -1.6 & 36 & New Zealand & -9.0 \\
\hline 37 Chile & -11.1 & 37 Latvia & -1.2 & 37 & Macedonia & -6.2 & 37 & Japan & -2.0 & 37 & Moldova & -9.5 \\
\hline 38 Malaysia & -12.9 & 38 Cyprus & -1.5 & 38 & Iran & -8.2 & 37 & Netherlands & -2.0 & 38 & Malaysia & -10.8 \\
\hline 39 Iran & -13.2 & 39 Lithuania & -3.7 & 39 & Japan & -11.1 & 39 & Korea & -2.6 & 39 & Ghana & -12.9 \\
\hline & & 40 Philippines & -4.7 & 40 & Malaysia & -11.7 & 40 & Estonia & -3.6 & & & \\
\hline & & 41 Moldova & -5.9 & 41 & Bulgaria & -11.8 & 41 & Norway & -4.0 & & & \\
\hline & & 42 Palestine & -7.5 & 42 & New Zealand & -12.9 & 42 & Chile & -4.1 & & & \\
\hline & & 43 Morocco & -9.7 & 43 & Serbia & -13.9 & 42 & Hungary & -4.1 & & & \\
\hline & & 44 Tunisia & -12.1 & & & & 44 & Moldova & -4.3 & & & \\
\hline & & 45 Israel & -12.6 & & & & 45 & New Zealand & -9.1 & & & \\
\hline & & 46 Ghana & -12.8 & & & & 46 & Sweden & -10.7 & & & \\
\hline$M$ & -0.2 & M & 2.5 & & $M$ & 2.6 & & $M$ & 2.2 & & $M$ & 2.5 \\
\hline$S D$ & 5.3 & $S D$ & 8.1 & & $S D$ & 9.8 & & $S D$ & 5.5 & & $S D$ & 7.5 \\
\hline
\end{tabular}

Note. The columns headed by percentage signs (\%) show the difference in each country between the percentages of students of high and low socioeconomic status (SES) taught by qualified teachers. For instance, in South Africa, 17.5\% more high-SES students than low-SES students were taught by fully certified teachers; in Korea, $0.3 \%$ fewer high-SES students than low-SES students were taught by fully certified teachers. The number before each country name indicates ranking based on the percentage difference for the teacher quality indicator for that column. Flemish Belgium refers to the Flemish-speaking population in Belgium. Data from the United States are bolded to show where the country stands cross-nationally.

aThe data on certification are not available from Flemish Belgium, Cyprus, England, Hungary, Latvia, the Netherlands, or Scotland.

bThe data on math education major are not available from Flemish Belgium, Italy, or Russia. 


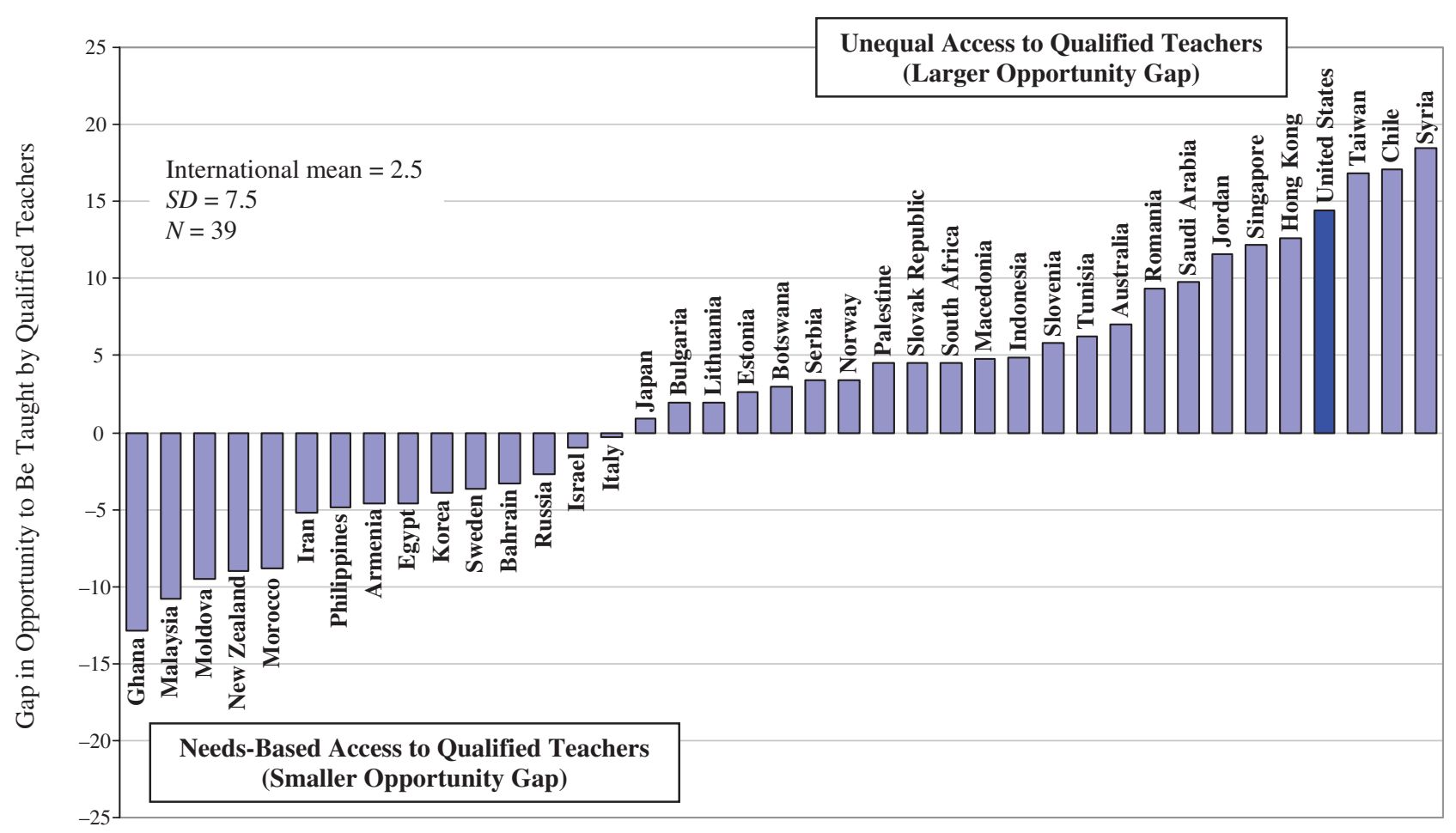

FIGURE 2. Opportunity gap: the difference between students of high and low socioeconomic status in access to qualified teachers in 2003.

students had greater access to fully certified teachers than did lowSES students. In the Unites States, the difference was 1.8, showing that there is no major difference between high-SES and low-SES students in their access to fully certified teachers.

When we look at the difference in student access to teachers with mathematics major and mathematics education major between high-SES and low-SES students, the data showed larger variations across countries. It varied from -12.8 in Ghana to 24.2 in Chile for mathematics major and -13.9 in Serbia to 42.4 in Chile for mathematics education major. In the size of the opportunity gap, the United States ranked 6th for mathematics major and 4th for mathematics education major. The percentage of high-SES students taught by teachers with a mathematics major was $10 \%$ higher than that of low-SES students $(54.1 \%$ vs. $44.1 \%$ ), and the percentage of high-SES students taught by teachers with a mathematics education major was $13.8 \%$ higher than that of low-SES students (59.9\% vs. $46.1 \%)$. There exists a major opportunity gap between high-SES and low-SES students in their access to teachers with a subject-specific major in the United States, and this gap is larger than those of most other countries compared here.

The gap in students' access to teachers with at least 3 years of teaching experience varied from -10.7 in Sweden to 16.6 in Syria. In Sweden and in New Zealand, where the gap is -9.1, lowSES students are more likely than high-SES students to be taught by experienced teachers. On the other hand, in Syria and in Tunisia, where the gap is 15.9, more low-SES students than highSES students are taught by less experienced teachers. In the United States, the gap was 3.6, with high-SES students having a slightly higher opportunity to be taught by experienced teachers, which is similar to the international average of 2.2.
However, when we investigated the opportunity gap between high-SES and low-SES students using all of these indicators, the United States ranked 4th among 39 countries. Figure 2 shows the countries that provide unequal access to qualified teachers and the countries that provide needs-based access to qualified teachers indicated by the size of opportunity gap.

In the United States, $67.6 \%$ of high-SES students were taught by teachers with full certification, mathematics or mathematics education major, and at least 3 years of teaching experience compared with $53.2 \%$ of low-SES students, showing the opportunity gap of $14.4 \%$. This is significantly larger than the international average of $2.5 \%$. The overall opportunity gap varied from -12.9 in Ghana to 18.5 in Syria. This large opportunity gap in access to qualified teachers between high-SES and low-SES students in the United States exacerbates the learning opportunity gap beyond the preexisting resource gap due to family's SES. What consequence could this inequality in the access to qualified teachers have on student outcome? Our final analysis explored this policy question.

\section{Teacher Quality, Opportunity Gap, and National Achievement Outcomes}

We examined the relationship between national levels of teacher quality and opportunity gaps in access to qualified teachers and national achievement outcomes: national mean mathematics score and SES-based achievement gap in mathematics scores through correlation and multiple regression analyses.

The correlation results showed that the percentage of students taught by fully certified teachers, the percentage of students taught by teachers with 3 or more years of teaching experience, and the percentage of students taught by teachers with high overall quality (full certification, mathematics or mathematic education major, and at 
Table 3

Multivariate Relationship Between Teacher Quality and National Achievement

\begin{tabular}{|c|c|c|c|c|c|}
\hline National Predictors & $\begin{array}{c}\text { Model } 1 \\
B(S E)\end{array}$ & $\begin{array}{c}\text { Model } 2 \\
B(S E)\end{array}$ & $\begin{array}{c}\text { Model } 3 \\
B(S E)\end{array}$ & $\begin{array}{c}\text { Model } 4 \\
B(S E)\end{array}$ & $\begin{array}{c}\text { Model } 5 \\
B(S E)\end{array}$ \\
\hline \multicolumn{6}{|l|}{ Teacher quality } \\
\hline Teacher certification & $2.71(1.16)^{*}$ & & & & \\
\hline Math major & & $0.55(0.63)$ & & & \\
\hline Math education major & & & $1.25(0.59)^{*}$ & & \\
\hline Teaching experience & & & & $5.20(1.57)^{* *}$ & \\
\hline Overall teacher quality & & & & & $2.04(0.54)^{* * *}$ \\
\hline \multicolumn{6}{|l|}{ National variables } \\
\hline Educational expenditure as \% of GDP & $-4.22(7.50)$ & $-6.67(7.68)$ & $-1.17(7.72)$ & $-1.62(6.68)$ & $-2.57(6.64)$ \\
\hline GDP per capita $(\$ 1,000)$ & $4.17(1.27)^{* *}$ & $4.98(1.33)^{* * *}$ & $4.55(1.25)^{* * *}$ & $4.10(1.08)^{* * *}$ & $5.21(1.12)^{* * *}$ \\
\hline$R^{2}$ & .43 & .33 & .41 & .50 & .56 \\
\hline$n$ & 29 & 34 & 31 & 34 & 29 \\
\hline
\end{tabular}

Note. $B=$ unstandardized regression coefficient; GDP = gross domestic product; $R^{2}=$ percentage of variance in the dependent variable explained by the independent variables.

${ }^{*} p<.05 .{ }^{* *} p<.01 .{ }^{* * *} p<.001$.

Table 4

Multivariate Relationship Between Opportunity Gap and Achievement Gap

\begin{tabular}{|c|c|c|c|c|c|}
\hline National Predictors & $\begin{array}{c}\text { Model } 1 \\
B(S E)\end{array}$ & $\begin{array}{c}\text { Model } 2 \\
B(S E)\end{array}$ & $\begin{array}{c}\text { Model } 3 \\
B(S E)\end{array}$ & $\begin{array}{c}\text { Model } 4 \\
B(S E)\end{array}$ & $\begin{array}{c}\text { Model } 5 \\
B(S E)\end{array}$ \\
\hline \multicolumn{6}{|l|}{ Opportunity gap } \\
\hline Teacher certification & $0.21(0.86)$ & & & & \\
\hline Math major & & $1.18(0.55)^{*}$ & & & \\
\hline Math education major & & & $0.72(0.43)$ & & \\
\hline Teaching experience & & & & $-1.49(0.82)$ & \\
\hline Overall teacher quality & & & & & $0.76(0.66)$ \\
\hline \multicolumn{6}{|l|}{ National variables } \\
\hline Educational expenditure as \% of GDP & $-2.21(2.95)$ & $-.51(2.71)$ & $-1.18(2.91)$ & $-1.62(2.68)$ & $-1.68(2.88)$ \\
\hline GDP per capita $(\$ 1,000)$ & $0.45(0.50)$ & $-0.06(0.48)$ & $0.41(0.48)$ & $0.21(0.45)$ & $0.28(0.51)$ \\
\hline$R^{2}$ & .05 & .16 & .13 & .13 & .09 \\
\hline$n$ & 29 & 34 & 31 & 34 & 29 \\
\hline
\end{tabular}

Note. $B=$ unstandardized regression coefficient; GDP = gross domestic product; $R^{2}=$ percentage of variance in the dependent variable explained by the independent variables.

${ }^{*} p<.05$.

least 3 years of experience) were significantly associated with higher national achievement. In addition, opportunity gaps in students' access to teachers with a mathematics major and to teachers with high overall quality were significantly associated with a larger achievement gap.

Based on these results, we conducted multiple regression analyses to examine: (a) the relationship between teacher quality and national achievement and (b) the relationship between opportunity gap and achievement gap, controlling for two national economic indicators: educational investment measured by educational expenditure as percentage of GDP and GDP per capita. The results are presented in Tables 3 and 4.

Five models with each of the teacher quality indicators are presented in these tables. The sample size varied from 29 to 34 because of the unavailability in some countries of data on educational expenditure as percentage of GDP and/or GDP per capita. Table 3 shows that all the teacher quality indicators except mathematics major were significantly and positively associated with national achievement. The countries where higher percentages of eighth graders were taught by fully certified teachers, teachers with a mathematics education major, teachers with at least 3 years of teaching experience, and teachers with high overall quality (a combination of four teacher quality indicators) achieved a significantly higher national average mathematics score than the other countries. A lack of a significant relationship between mathematics major and national achievement shows that holding a mathematics major alone may not show that a teacher is effective in improving student achievement. However, when mathematics major is accompanied by full certification and teaching experience, the teacher is likely to effectively facilitate student learning, as shown in the significant relationship between overall teacher quality and student achievement. Our data confirmed the importance of ensuring a qualified teaching workforce to produce higher national achievement.

Does an opportunity gap in students' access to qualified teachers result in a larger achievement gap? Table 4 shows that the 
relationship between the independent variables and opportunity gap and achievement gap was not as strong as the relationship between the independent variables and teacher quality and national achievement. It shows that the opportunity gap measured by the difference in the percentages of high-SES students and low-SES students taught by teachers with mathematics major was significantly and positively associated with achievement gap, but no other opportunity gap indicators showed a significant relationship.

This lack of significant relationship may be due to cross-national differences in how the opportunity gap leads to the achievement gap. For example, as shown in Figure 2, high-achieving Asian countries such as Hong Kong and Singapore have the highest level of opportunity gap, similar to that of the United States. However, in these countries, the impact of the opportunity gap in students' access to qualified teachers may be minimized because of equity in school resources and opportunities for teacher learning. These countries have centralized education systems in which the government ensures the equal distribution of material resources for instruction. Hong Kong and Singapore were found to be among the countries with the lowest levels of inequality in school resources (e.g., instructional resources, building conditions, and class size) in a comparative study of 52 countries (Baker et al., 2005). In Singapore, the National Institute of Education, in collaboration with the Ministry of Education, provides teachers with various professional development pathways through which they can systematically upgrade their professional knowledge and practices according to their talents and aspirations based on professional development continuum models (Tan, 2005). Participation in professional development is required for teachers seeking promotion in Hong Kong as well (Wang et al., 2003).

These teacher learning opportunities, combined with equal resource allocations, are likely to reduce the initial gap in teacher qualifications by improving teacher practices through mentorship and collaboration among teachers. These may be possible reasons why Hong Kong and Singapore do not have large achievement gaps (see Figure 1) despite the large opportunity gaps between high-SES and low-SES students in their access to qualified teachers. ${ }^{9}$

In sharp contrast, in some countries, including the United States, where the teacher qualification gap is likely to be accompanied by gaps in teachers' access to instructional resources and professional development opportunities, the impact of the gap in opportunity to be taught by qualified teachers is likely to be further enhanced, thereby increasing the achievement gap. Because there are many mediators that either enhance or mitigate the impact of an opportunity gap on the corresponding achievement gap, and the mediators and processes are likely to vary across countries, the relationship between opportunity gap and achievement gap is not as straightforward as the relationship between teacher quality and national achievement.

Mathematics major as a measure of teacher content preparation and knowledge is unique because teachers' mathematics knowledge may have more to do with an innate ability and therefore be more difficult to develop through learning opportunities or provision of resources. Thus, students taught by teachers with a mathematics major may benefit from mathematics instruction more focused on concepts and higher order thinking than students taught by teachers without a mathematics major. The complexity of the relationship between opportunity gap and achievement gap points us to the importance of exploring cross-national differences in mediators and processes.

\section{Discussion}

This cross-national study of 46 countries investigated an important focus of educational reforms around the world-teacher quality. Despite the important role teachers play in promoting student learning, systematic cross-national analysis of the effect of teacher quality on educational achievement has been limited. This study used the largest international database available (the 2003 TIMSS) and not only compared teacher quality and the opportunity gap in the United States with those in 45 other countries but also conducted cross-national analyses of the relationships between teacher quality, opportunity gap, national achievement, and achievement gap.

Comparisons of the national levels of teacher quality and opportunity gap between high-SES and low-SES students in their access to qualified teachers offer an important insight into our efforts to achieve both high standards and equity in the quality of the teaching workforce. The data show that many countries that have achieved an overall high-quality teaching workforce do not necessarily offer equal access to qualified teachers across students of various socioeconomic statuses. For example, in Slovenia and Romania, more than $80 \%$ of eighth graders are taught by qualified teachers who have met the criteria for full certification, have completed a mathematics or mathematics major, and had 3 or more years of teaching experience. However, a significantly higher percentage of high-SES than low-SES students are taught by qualified teachers. In contrast, in New Zealand and Ghana, less than $40 \%$ of students are taught by qualified teachers, but low-SES students have more access to those qualified teachers than do high-SES students. In other countries, such as the United States and Australia, about $60 \%$ of students are taught by qualified teachers - a level similar to the international average of $62 \%$-yet the opportunity gap is larger than the international average (14\% in the United States and $7 \%$ in Australia, as compared with the international average of $2.5 \%$ ).

These data show the difficulty of achieving high overall teacher quality while ensuring that all teachers possess the quality determined by each country. There are many reasons why this is not an easy task. High demand for teachers with a limited supply of teacher candidates can be one reason, and lack of resources for teachers to meet the requirements set by the government can be another. The reasons are likely to vary across countries. One approach to determining how to achieve both excellence in the teaching workforce and equity in access to teacher quality is to study the countries that have achieved this difficult goal. Our data showed that South Korea and Russia have achieved both a high percentage of students taught by qualified teachers and equality of access to qualified teachers by high-SES and low-SES students. An in-depth study of how these countries achieved both excellence and equity in teacher quality will provide useful information for U.S. policy makers.

Our analysis further revealed that the higher achieving countries had a higher percentage of students taught by teachers who had met their country's criteria for full certification, had majored in mathematics or mathematics education, and had accumulated at least 3 years of teaching experience. This means that when a 
country ensures that most students are taught by such teachersregardless of the specific requirements in that country-its students are likely to achieve higher.

Given that all of the countries studied here have teacher candidates with various abilities, we conclude that the countries with higher percentages of students taught by qualified teachers are likely to have established successful methods of recruiting the best qualified candidates into teaching and ensuring that only the candidates who pass multiple screening criteria are allowed to teach (Wang et al., 2003). Our study provided evidence that investing in teacher quality, among other school factors, is a good way to improve student learning outcomes, but it is also important to ensure that all students are taught by highly qualified teachers.

Promoting high achievement by all students regardless of their SES, race/ethnicity, or other individual backgrounds is a major educational goal of any democratic society (Banks, 2007). Highly educated citizens will be well informed of their rights and responsibilities and will actively participate in formal and informal efforts to improve the society. Our previous study showed that a country with a large achievement gap is likely to have a higher level of school violence (Akiba, 2004; Akiba, LeTendre, Baker, \& Goesling, 2002). Educational inequality is likely to lead to other factors that interfere with the healthy development of school-aged children. Thus, achieving equity by offering equal learning opportunities to all students is an important policy goal in all countries.

In the United States, where race and SES are intimately related, unequal access to qualified teachers adds an element of racial inequality to the education policy debate (see Friedman, 2005, p. 20). In a separate cross-national analysis of race and student achievement, Boe and Shin (2005) found "compelling evidence that the low scores of these two groups of minority students were major factors in reducing the comparative standing of the U.S. in international surveys of achievement" (p. 695). Race-based differences in access to qualified teachers are therefore a powerful political issue that will continue to engage policy makers.

Despite the fact that teacher quality is a major source of inequality in students' learning opportunities, our data showed that the opportunity gap in students' access to qualified teachers was not significantly associated with achievement gap between high-SES and low-SES students. Ensuring students' equal access to teachers with full certification, a mathematics or mathematics education major, and at least 3 years of teaching experience alone does not lead to a narrowed achievement gap.

We argue that variations within countries in resources for instruction and learning opportunities provided to teachers are likely to explain this lack of a significant relationship. Some countries, such as Singapore and Hong Kong, provide equal instructional resources and ample opportunities for teacher learning, which would compensate for the initial gap in teacher qualifications. In the United States, instructional resources and learning opportunities tend to correlate with initial teacher qualifications because of the decentralized funding system based on local property taxes. Therefore, to reduce the achievement gap between high-SES and low-SES students, narrowing the gap in their access to qualified teachers in terms of their credentials and teaching experience alone is not sufficient. The government needs to pay attention to important mediators that lead to effective instructional practice among all teachers. Identifying such mediators, which are likely to differ from country to country, is an important direction for future research on teacher quality.

\section{Policy Implications}

Studies of cross-national achievement, whether conducted by the IEA or OECD, now play a major role in U.S. education policy discourse. A study of factors (databases, organizations, and individuals) affecting U.S. education policy (Swanson \& Barlage, 2006) found that the TIMSS had "the second-highest overall influence index value” (p. ii). Improvements in cross-national research design (see Porter \& Gamoran, 2002) now allow the data from such studies to be used to directly assess the impact of teacher quality on student learning outcomes.

Our data showed that although the United States produced a higher level of national achievement than the international average in eighth-grade mathematics in 2003, the U.S. achievement gap between high-SES and low-SES students was among the largest. The achievement of excellence as measured by national achievement level and equity of outcomes among students of various SES and ethnic backgrounds is a major goal that the United States has strived to achieve over the years.

The national level of teacher quality in the United States, as measured by percentage of students taught by qualified teachers, did not fall behind most countries. However, a major difference was observed between high-SES students and low-SES students in their opportunity to be taught by qualified teachers; the U.S. opportunity gap was fourth-highest among 46 countries. This inequality likely originates from the funding inequality between districts and schools under the decentralized U.S. funding system, which draws school funding mainly from local property taxes (Kozol, 1991, 2005). In addition, concomitant economic, ethnic, and racial segregation contribute to the inequality (Kozol, 2005). The funding inequality typically results in a complex interaction of inequality in teacher salaries, school resources, class sizes, and curriculum offerings, all of which undermine a district's ability to attract (and keep) qualified teachers (see Smith, 2006, for a study of state-level interventions designed to reduce teacher turnover). High-poverty districts, where low-SES and minority youths are often concentrated, typically have no choice but to hire underqualified (i.e., non-subject-trained) teachers because of the combined influences of high turnover rates and more difficult working conditions (Darling-Hammond \& Sykes, 2003).

Such funding inequality does not exist in many other countries that ensure equal access to qualified teachers among students or provide a higher level of access to qualified teachers for disadvantaged students. In comparison with the $14.4 \%$ difference in the percentage of high-SES and low-SES students taught by qualified teachers in the United States, 21 countries had less than a $5 \%$ difference; furthermore, 15 countries, including Malaysia, New Zealand, and Ghana, provided a higher level of access to qualified teachers for low-SES students. Many of these countries have centralized education systems that guarantee equal or needsbased funding allocation to schools. Others, such as Japan, implement regional hiring and assignment of teachers with periodic rotation specifically designed to reduce school-based differences in overall teacher quality.

Our data showed that although investing in teacher quality is likely to produce high national achievement, narrowing the 
opportunity gap in students' access to qualified teachers does not by itself lead to a narrowed achievement gap. Because teaching is a profession that requires continuous learning, it is crucial to provide teachers with sufficient learning opportunities and instructional resources to enable them to continuously improve instruction. To develop effective instructional practices, mathematics teachers need to learn about students' prior experiences and knowledge related to mathematics, reflect on their own beliefs about mathematics learning, and continuously experiment with new instructional approaches. With one third of U.S. teachers teaching mathematics without a major in mathematics or mathematics education, it is especially important that they have the continuous learning opportunities and resources necessary for instructional improvement.

NCLB's requirements of full certification and subject-specific preparation are supported by our data, which established the link between high national achievement and a higher percentage of students taught by fully certified teachers with mathematics or mathematics education majors. However, without providing equal and continuous learning opportunities and resources for instructional improvement to all teachers, NCLB is unlikely to promote student learning or narrow the achievement gap.

Our data showed that other decentralized educational systems serving diverse populations, as in Australia and Sweden, produce smaller opportunity gaps and smaller achievement gaps between high-income and low-income students than those in the United States. These data show that it is possible for the United States to improve student access to qualified teachers and to narrow the achievement gap. Future international studies that uncover the characteristics of teacher quality policy and the role of federal government in successful countries can provide useful information from which U.S. policy makers can learn.

The achievement gap in the United States has not narrowed for many years (Harris \& Herrington, 2006). The opportunity gap in access to qualified teachers has always been a major problem in this country, and the nature of such inequality is well documented (Darling-Hammond, 2006); yet there has been no systemic effort at the federal or state level to address this inequality. In NCLB, districts and schools are held accountable for student outcomes but not for narrowing the inequality in students' access to qualified teachers and other resources. Districts need to be given additional resources and incentives to attract and retain highly qualified teachers for the students who need them the most. As Smith (2006) demonstrates, innovative state-level programs are a potentially useful tool.

However, we note Rockoff s (2004) caution: "The empirical evidence above suggests that raising teacher quality may be a key instrument in improving student outcomes. However, . . . policies that reward teachers based on credentials may be less effective than policies that reward teachers based on performance" (p. 251). Some nations (notably the high-performing East Asian countries) appear to have found other mechanisms that ensure high levels of student achievement. Ongoing teacher professional development and the equalization of instructional resources may prove to be equally or more effective than the credential requirements specified under NCLB.

For decades, researchers and reformers have called for more wideranging reforms that directly address school-based inequities in the quality of education that students receive. The international data show yet again the magnitude of the problem in the United States. They also appear to show that many nations have successfully addressed this issue without recourse either to highly centralized educational bureaucracies or to radical free-market reforms of public education. Determining how nations solve dilemmas of equity in access to highly qualified teachers is a promising area of study that offers more potentially policy-relevant information than continued emphasis on national scores and the global horse race to gain the top score.

\section{NOTES}

${ }^{1}$ Although Taiwan and Hong Kong are parts of the Republic of China, not independent countries, they are counted as countries in this article. Similarly, Flemish Belgium refers to the Flemish-speaking population in Belgium.

${ }^{2}$ The study by Boyd, Grossman, Lankford, Loeb, and Wyckoff (2006) and other studies summarized by Rice (2003) did not use panel data on teachers (e.g., following the same group of teachers for 5 years) to examine the impact of teaching experience on student achievement. For example, Boyd et al.'s study correlated teacher experience (in number of years) and student achievement increase over 1 year and found that the teachers who taught for 2 and 3 years had significantly larger achievement increases in the mathematics and English language arts scores of their students than did 1styear teachers. However, there was no difference between the teachers with more than 3 years of experience and teachers with 3 years of experience in their effectiveness in improving student mathematics and English language arts scores. This is the method taken by all of the existing studies on the impact of teaching experience on student achievement.

${ }^{3}$ Ingersoll (2001) argued that "school staffing problems are not primarily due to teacher shortages.... The data indicate that school staffing problems are primarily due to excess demand resulting from a 'revolving door'-where large numbers of teachers depart their jobs for reasons other then retirement" (p. 499).

${ }^{4} \mathrm{~A}$ systemic probability-proportional-to-size technique was used to choose schools in the first sampling stage. The number of eighth graders was obtained for each school and was used as the measure of size to determine the probability for selecting each school. If larger schools have a higher probability of selection, students will have more nearly equal chances to be selected regardless of the size of the school where they are enrolled. For further technical details, see the TIMSS 2003 Technical Report (Martin, Mullis, \& Chrostowski, 2004, pp. 118-121).

${ }^{5}$ Parental income, parental education, and parental occupation were generally used for computing socioeconomic status (SES) in the past studies (Hauser, 1994). Because of the unavailability of parental income and occupation in the Trends in International Mathematics and Science Study (TIMSS) data set, in this study the measure of the SES of students was based on the education level of their parents, the existence of educational resources at home (calculator, computer, study desk or table, and dictionary), and the number of books at home. It was standardized around the mean in each nation.

${ }^{6}$ The data from 2003 were collected to match with the TIMSS 2003 data. For the countries without 2003 data, the data from the most recent year were used. The educational expenditure as percentage of gross domestic product (GDP) varied from $1.2 \%$ in Indonesia to $8.3 \%$ in Saudi Arabia, with a mean of $5.1 \%$ and a standard deviation of 1.6. The GDP per capita in US $\$ 1,000$ ranged from $2.2(\$ 2,200)$ in Ghana to $37.7(\$ 37,700)$ in Norway, with a mean of 15.5 and a standard deviation of 10.2. Although it is common to compute the log of GDP per capita in cross-national studies to reduce skewness, we used the original data without logging because the data were not skewed in the group of countries analyzed here. 
${ }^{7}$ The figure of $100 \%$ for Armenia and Latvia does not mean that there were no new teachers in these countries. It means that the percentage of new teachers was very small, and they were not selected as part of the samples.

${ }^{8}$ Readers could argue that when low-SES students have greater access to qualified teachers than do high-SES students, the opportunity gap favors the low-SES students. However, such a gap is likely the result of a government policy or system that attempts to promote greater equality in students' opportunity to learn, based on the preexisting disadvantage of low-SES students as compared with high-SES students. Therefore, we consider the opportunity gap to be smaller in a national context where low-SES students have greater access to qualified teachers.

${ }^{9}$ We must also consider the impact of high-quality early childhood education and care. The Innocenti Centre's research (United Nations Children's Fund, 2002, p. 27) emphasizes the positive impact of highquality early childhood interventions in counteracting the impact of poverty. Work by Tobin, Wu, and Davidson (1989) suggests that both Japan and China have made provision of early childhood education a high priority. Given these high levels of basic support, the impact of teacher qualification may be reduced.

\section{REFERENCES}

Akiba, M. (2004). A cross-national analysis of student victimization: Educational inequality and school violence. In S. Paik (Ed.), Productivity analyses of national databases (pp. 205-224). Greenwich, CT: Information Age.

Akiba, M., LeTendre, G., Baker, D., \& Goesling, B. (2002). Student victimization: National and school system effects on school violence in 37 nations. American Educational Research Journal, 39(4), 829-853.

Anderson-Levitt, K. (2001). Teaching culture. Cresskill, NJ: Hampton Press. Anderson-Levitt, K. (2005). The schoolyard gate: Schooling and childhood in global perspective. Journal of Social History, 38(4), 987-1006.

Ascher, C., \& Fruchter, N. (2001). Teacher quality and student performance in New York City's low-performing schools. Journal of Education for Students Placed at Risk, 6(3), 199-214.

Baker, D. P., Goesling, B., \& LeTendre, G. K. (2002). Socioeconomic status, school quality, and national economic development: A cross-national analysis of the "Heyneman-Loxley Effect" on mathematics and science achievement. Comparative Education Review, 46(3), 291-312.

Baker, D. P., LeTendre, G. K., \& Goesling, B. (2005). Rich land, poor schools: Inequality of national educational resources and achievement of disadvantaged students. In D. P. Baker \& G. K. LeTendre (Eds.), National differences, global similarities (pp. 71-85). Stanford, CA: Stanford University Press.

Banks, J. A. (2007). Diversity and citizenship education: Global perspectives. San Francisco: Jossey-Bass.

Benavot, A., \& Braslavsky, C. (Eds.). (2006). School knowledge in comparative and historical perspective: Changing curricula in primary and secondary education. Hong Kong: Comparative Education Research Centre.

Benavot, A., Cha, Y., Kamens, D., Meyer, J., \& Wong, S. (1991). Knowledge for the masses: World models and national curricula, 1920-1986. American Sociological Review, 56(1), 85-100.

Blank, R. (2003). Meeting NCLB goals for highly qualified teachers: Estimates by state from survey data. Washington, DC: Council of Chief State School Officers.

Boe, E., \& Shin, S. (2005). Is the United States really losing the international horse race in academic achievement? Phi Delta Kappan, 86(9), 688-696.

Borman, G., \& Kimball, S. (2005). Teacher quality and educational equality: Do teachers with higher standards-based evaluation ratings close student achievement gaps? Elementary School Journal, 106(1), 3-20.

Boyd, D., Grossman, P., Lankford, H., Loeb, S., \& Wyckoff, J. (2006). How changes in entry requirements alter the teacher workforce and affect student achievement. Education Finance and Policy, 1(2), 176-215.
Cohen-Vogel, L. (2005). Federal role in teacher quality: "Redefinition" or policy alignment? Educational Policy, 19(1), 18-43.

Darling-Hammond, L. (2000). Teacher quality and student achievement: A review of state policy evidence. Education Policy Analysis Archives, 8(1). Retrieved December 1, 2006, from http://epaa.asu.edu/epaa/v8n1/

Darling-Hammond, L. (2004). Inequality and the right to learn: Access to qualified teachers in California's public schools. Teachers College Record, 106(10), 1936-1966.

Darling-Hammond, L. (2006). Securing the right to learn: Policy and practice for powerful teaching and learning. Educational Researcher, 35(7), 13-24.

Darling-Hammond, L., \& Sykes, G. (2003). Wanted: A national teacher supply policy for education: The right way to meet the "highly qualified teacher" challenge. Education Policy Analysis Archives, 11(3). Retrieved December 1, 2006, from http://epaa.asu.edu/epaa/v11n3/

Darling-Hammond, L., \& Youngs, P. (2002). Defining "highly qualified teachers": What does "scientifically-based research" actually tell us? Educational Researcher, 31(9), 13-25.

Desimone, L., Smith, T., Baker, D., \& Ueno, K. (2005). Assessing barriers to the reform of U.S. mathematics instruction from an international perspective. American Educational Research Journal, 42(3), 501-535.

Druva, C. A., \& Anderson, R. D. (1983). Science teacher characteristics by teacher behavior and by student outcome: A meta-analysis of research. Journal of Research in Science Teaching, 20(5), 467-479.

Eberts, R. W., \& Stone, J. A. (1984). Unions and public schools. Lexington, MA: D. C. Heath.

Ferguson, R. F., \& Womack, S. T. (1993). The impact of subject matter and education coursework on teaching performance. Journal of Teacher Education, 44(1), 55-63.

Floden, R. (2002). The measurement of opportunity to learn. In A. Porter \& A. Gamoran (Eds.), Methodological advances in cross-national surveys of educational achievement (pp. 231-266). Washington, DC: National Academy Press.

Friedman, M. (2005, November). Education: The next 50 years. American Spectator, 38, 18-20.

Ginsburg, A., Cooke, G., Leinwand, S., Noell, J., \& Pollock, E. (2005). Reassessing U.S. international mathematics performance: New findings from the 2003 TIMSS and PISA. Washington, DC: U.S. Department of Education and American Institutes for Research.

Givvin, K., Hiebert, J., Jacobs, J., Hollingsworth, H., \& Gallimore, R. (2005). Are there national patterns of teaching? Evidence from the TIMSS 1999 video study. Comparative Education Review, 49(3), 311-343.

Goldhaber, D. D., \& Brewer, D. J. (1997). Why don't schools and teachers seem to matter? Assessing the impact of unobservables on educational productivity. Journal of Human Resources, 32(3), 505-523.

Goldhaber, D. D., \& Brewer, D. J. (2000). Does teacher certification matter? High school teacher certification status and student achievement. Educational Evaluation and Policy Analysis, 22(2), 129-146.

Greenwald, R., Hedges, L. V., \& Laine, R. D. (1996). The effect of school resources on student achievement. Review of Educational Research, 66(3), 361-396.

Hacsi, T. (2002). Children as pawns: The politics of educational reform. Cambridge, MA: Harvard University Press.

Hampden-Thompson, G., \& Johnston, J. S. (2006). Variation in the relationship between nonschool factors and student achievement on international assessments. Washington, DC: U.S. Department of Education, Institute of Education Sciences.

Harris, D. N., \& Herrington, C. D. (2006). Accountability, standards, and the growing achievement gap: Lessons from the past half-century. American Journal of Education, 112(2), 209-238.

Hauser, R. M. (1994). Measuring socioeconomic status in studies of child development. Child Development, 65(6), 1541-1545. 
Hawk, P. P., Coble, C. R., \& Swanson, M. (1985). Certification: It does matter. Journal of Teacher Education, 36(3), 13-15.

Hiebert, J., Stigler, J. W., Jacobs, J. K., Givvin, K. B., Garnier, H., Smith, M. S., et al. (2005). Mathematics teaching in the United States today (and tomorrow): Results from the TIMSS 1999 video study. Educational Evaluation and Policy Analysis, 27(2), 111-132.

Ingersoll, R. M. (1999). The problem of underqualified teachers in American secondary schools. Educational Researcher, 28(2), 26-37.

Ingersoll, R. M. (2001). Teacher turnover and teacher shortages. American Educational Research Journal, 38(3), 499-534.

Ingersoll, R. M. (2002). The teacher shortage: A case of wrong diagnosis and wrong prescription. NASSP Bulletin, 86(631), 16-31.

Jerald, C., \& Ingersoll, R. M. (2002). All talk, no action: Putting an end to out-of-field teaching. Washington, DC: Education Trust. Retrieved November 15, 2006, from www.edtrust.org/main/documents/AllTalk.pdf

Kozol, J. (1991). Savage inequalities: Children in America's schools. New York: Crown.

Kozol, J. (2005). The shame of the nation: The restoration of apartheid schooling in America. New York: Crown.

Lawrenz, F. (1975). The relationship between science teacher characteristics and student achievement and attitude. Journal of Research in Science Teaching, 12(4), 433-437.

LeTendre, G. (1994). Guiding them on: Teaching, hierarchy, and social organization in Japanese middle schools. Journal of Japanese Studies, 20(1), 37-59.

LeTendre, G. K. (1995). Disruption and reconnection: Counseling young adolescents in Japanese Schools. Educational Policy, 9(2), 169-184.

Le'Tendre, G., Baker, D., Akiba, M., Goesling, B., \& Wiseman, A. (2001). Teachers' work: Institutional isomorphism and cultural variation in the U.S., Germany, and Japan. Educational Researcher, 30(6), 3-15.

LeTendre, G., Baker, D., Akiba, M., \& Wiseman, A. (2001). The policy trap: National educational policy and the Third International Math and Science Study. International Journal of Educational Policy Research and Practice, 2(1), 45-64.

LeTendre, G., Hofer, B. K., \& Shimizu, H. (2003). What is tracking? Cultural expectations in the United States, Germany, and Japan. American Educational Research Journal, 40(1), 43-89.

Ma, L. (1999) Knowing and teaching elementary mathematics: Teachers' understanding of fundamental mathematics in China and the United States. Mahwah, NJ: Lawrence Erlbaum.

Martin, M., Mullis, I., \& Chrostowski, S. (Eds.). (2004). TIMSS 2003 technical report. Boston: TIMSS and PIRLS International Study Center.

Meyer, J., Ramirez, F., \& Soysal, Y. N. (1992). World expansion of mass education, 1870-1980. Sociology of Education, 65(2), 128-149.

Monk, D. H. (1994). Subject area preparation of secondary mathematics and science teachers and student achievement. Economics of Education Review, 13(2), 125-145.

Monk, D. H., \& King, J. A. (1994). Multilevel teacher resource effects in pupil performance in secondary mathematics and science: The case of teacher subject-matter preparation. In R. G. Ehrenberg (Ed.), Choices and consequences: Contemporary policy issues in education (pp. 29-58). Ithaca, NY: ILR Press.

National Academies. (2007). Study of teacher preparation programs in the United States. Retrieved December 1, 2006, from http://www .nationalacademies.org/teacherprep/

National Center for Education Statistics. (2000). Monitoring quality: An indicators report. Washington, DC: Author.

Organisation for Economic Co-operation and Development. (2004). The quality of the teaching workforce. Paris: Author.

Organisation for Economic Co-operation and Development. (2005). Teachers matter: Attracting, developing and retaining effective teachers. Paris: Author.
Osborn, M., Broadfoot, P., McNess, E., Planel, C., Ravn, B., \& Triggs, P. (2003). A world of difference? Comparing learners across Europe. Maidenhead, UK: Open University Press.

Peske, H. G., \& Haycock, K. (2006). Teaching inequality: How poor and minority students are shortchanged on teacher quality. Washington, DC: Education Trust.

Porter, A., \& Gamoran, A. (Eds.). (2002). Methodological advances in cross-national surveys of educational achievement. Washington, DC: National Academy Press.

Ramirez, F. O., \& Boli, J. (1987). The political construction of mass schooling: European origin and worldwide institutionalization. Sociology of Education, 60(1), 2-17.

Rice, J. K. (2003). Teacher quality: Understanding the effectiveness of teacher attributes. Washington, DC: Economic Policy Institute.

Rivkin, S., Hanushek, E., \& Kain, J. (2005). Teachers, schools and academic achievement. Econometrica, 73(2), 417-458.

Rockoff, J. (2004). The impact of individual teachers on student achievement: Evidence from panel data. American Economic Review, 94(2), 247-252.

Rowan, B., Chiang, F., \& Miller, R. J. (1997). Using research on employees' performance to study the effects of teachers on students' achievement. Sociology of Education, 70(4), 256-284.

Rowan, B., Correnti, R., \& Miller, R. J. (2002). What large-scale, survey research tells us about teacher effects on student achievement: Insights from the Prospects study of elementary schools. Teachers College Record, 104, 1525-1567.

Schmidt, W., McKnight, C., Houang, R., Wang, H., Wiley, D., Cogan, L., et al. (2001). Why schools matter: A cross-national comparison of curriculum and learning. San Francisco: Jossey-Bass.

Seastrom, M. M., Gruber, K. J., Henke, R. R., McGrath, D. J., \& Cohen, B. A. (2002). Qualifications of the public school teacher workforce: Prevalence of out-of-field teaching, 1987-88 to 1999-2000. Washington, DC: National Center for Education Statistics.

Sheehan, D. S., \& Marcus, M. (1978). Teacher performance on national teacher examinations and student mathematics and vocabulary achievement. Journal of Educational Research, 71(3), 134-136.

Shen, J., Mansberger, N. B., \& Yang, H. (2004). Teacher quality and students placed at risk: Results from the Baccalaureate and Beyond Longitudinal Study, 1993-97. Educational Horizons, 82(3), 226-235.

Shimahara, N., \& Sakai, A. (1995). Learning to teach in two cultures. New York: Garland.

Siniscalco, M. (2002). A statistical profile of the teaching profession. Paris: International Labor Office and United Nations Educational, Scientific and Cultural Organization.

Smith, T. (2006). How do state-level induction and standards-based reform policies affect induction experiences and turnover among new teachers? American Journal of Education, 113(2), 273-310.

Stein, S. (2004). The culture of education policy. New York: Teachers College Press.

Steiner-Khamsi, G. (2004). The global politics of educational borrowing and lending. New York: Teachers College Press.

Stigler, J., \& Stevenson, H. (1991). How Asian teachers polish each lesson to perfection. American Educator, 15(1), 12-20.

Stigler, J. W., \& Hiebert, J. (1999). The teaching gap: Best ideas from the world's teachers for improving education in the classroom. New York: Free Press.

Strauss, R. P., \& Sawyer, E. A. (1986). Some new evidence on teacher and student competencies. Economics of Education Review, 5(1), 41-48.

Summers, A. A., \& Wolfe, B. L. (1977). Do schools make a difference? American Economic Review, 67(4), 639-652.

Swanson, C., \& Barlage, J. (2006). Influence: A study of the factors shaping education policy. Bethesda, MD: Editorial Projects in Education.

Tan, K. S. S. (2005, April). Professional development and lifelong learning: Towards building a quality education service in Singapore. Paper 
presented at the First International Symposium on Qualification Systems for Teachers (ISQST), Beijing, China.

Tobin, J., Wu, D., \& Davidson, D. (1989). Preschools in three cultures: Japan, China and the United States. New Haven, CT: Yale University Press.

UNESCO Institute for Statistics. (1998-2006). UNESCO statistical yearbook. Paris: Author.

UNESCO Institute for Statistics. (2006). Teachers and educational quality: Monitoring global needs for 2015. Montréal, Canada: Author.

United Nations Children's Fund. (2002). A league table of educational disadvantage in rich nations (Innocenti Report Card 4). Florence, Italy: UNICEF Innocenti Research Centre.

United Nations Children's Fund. (2007). Child poverty in perspective: An overview of child well-being in rich countries (Innocenti Report Card 7). Florence, Italy: UNICEF Innocenti Research Centre.

U.S. Department of Education. (2006a). Letter to the Chief State School Officers regarding states' good-faith efforts in meeting the highly qualified teachers goal. Washington, DC: Author. Retrieved December 1, 2006, from http:/www.ed.gov/programs/teacherqual/hqtltr/index.html

U.S. Department of Education. (2006b). The Secretary's fifth annual report on teacher quality: A highly qualified teacher in every classroom. Washington, DC: U.S. Department of Education.

Wang, A. H., Coleman, A. B., Coley, R. J., \& Phelps, R. P. (2003). Preparing teachers around the world. Princeton, NJ: Educational Testing Service.

Wayne, A. J., \& Youngs, P. (2003). Teacher characteristics and student achievement gains: A review. Review of Educational Research, 73(1), 89-122.

Welmond, M. (2002). Globalization viewed from the periphery: The dynamics of teacher identity in the Republic of Benin. Comparative Education Review, 46(1), 37-65.
Wilson, S. M., Floden, R. E., \& Ferrini-Mundy, J. (2001). Teacher preparation research: Current knowledge, gaps, and recommendations. Seattle, WA: Center for the Study of Teaching and Policy.

Wilson, S. M., Floden, R. E., \& Ferrini-Mundy, J. (2002). Teacher preparation research: An insider's view from the outside. Journal of Teacher Education, 53(3), 190-204.

\section{AUTHORS}

MOTOKO AKIBA is an assistant professor in the Department of Educational Leadership and Policy Analysis at the University of Missouri, Columbia, 202 Hill Hall, Columbia, MO 65211; akibam@missouri.edu. Her research interests include teacher quality and learning, multicultural teacher education, and school safety.

GERALD K. LETENDRE is a professor in the Department of Education Policy Studies at Pennsylvania State University, 310G Rackley, University Park, PA 16802; letendre@psu.edu. His research focuses on global trends in teacher working conditions and the diffusion and institutionalization of drug prevention programs in public schools worldwide.

JAY P. SCRIBNER is an associate professor in the Department of Educational Leadership and Policy at the University of Missouri, 202 Hill Hall, Columbia, MO 65211; scribnerj@missouri.edu. His research interests include organizational learning, professional development, and teacher quality. 
APPENDIX A

Descriptive Statistics of Teacher Quality Variables at Teacher Level

\begin{tabular}{|c|c|c|c|c|c|c|c|c|c|c|c|c|c|}
\hline \multirow[b]{3}{*}{ Country } & \multirow{2}{*}{\multicolumn{4}{|c|}{ Certification }} & \multicolumn{4}{|c|}{ Math/Math Education Major } & & & & & \\
\hline & & & & & \multirow{2}{*}{$\begin{array}{c}\text { Math } \\
\text { Major } \\
\%\end{array}$} & \multirow{2}{*}{$\begin{array}{c}\text { Math } \\
\text { Education } \\
\text { Major } \\
\%\end{array}$} & \multirow{2}{*}{$\begin{array}{c}\text { Both } \\
\text { Majors } \\
\%\end{array}$} & \multirow{2}{*}{$\begin{array}{l}\text { No } \\
\text { Major } \\
\%\end{array}$} & \multicolumn{5}{|c|}{ Teaching Experience } \\
\hline & $\begin{array}{c}\text { Total } \\
n\end{array}$ & $\begin{array}{c}\text { Certified } \\
\%\end{array}$ & $\begin{array}{c}\text { Not } \\
\text { Certified } \\
\%\end{array}$ & $\begin{array}{c}\text { Total } \\
n\end{array}$ & & & & & $n$ & $M$ & Minimum & Maximum & $S D$ \\
\hline Armenia & 163 & 100.0 & 0.0 & 180 & 45.0 & 6.0 & 36.6 & 12.4 & 166 & 19.6 & 3 & 50 & 9.7 \\
\hline Australia & 180 & 95.8 & 4.2 & 196 & 15.7 & 13.0 & 44.9 & 26.4 & 190 & 15.5 & 1 & 40 & 9.6 \\
\hline Bahrain & 113 & 87.3 & 12.7 & 120 & 8.3 & 46.9 & 40.5 & 4.3 & 110 & 11.3 & 1 & 34 & 8.3 \\
\hline $\begin{array}{l}\text { Flemish } \\
\text { Belgium }\end{array}$ & - & - & - & 229 & 94.7 & - & - & 5.3 & 229 & 17.8 & 1 & 43 & 11.1 \\
\hline Botswana & 124 & 100.0 & 0.0 & 132 & 45.3 & 17.7 & 32.6 & 4.4 & 121 & 6.4 & 1 & 26 & 5.1 \\
\hline Bulgaria & 157 & 100.0 & 0.0 & 171 & 15.6 & 1.1 & 79.7 & 3.5 & 166 & 20.3 & 1 & 41 & 8.6 \\
\hline Chile & 171 & 92.7 & 7.3 & 191 & 31.9 & 9.3 & 19.4 & 39.4 & 189 & 21.8 & 1 & 46 & 10.7 \\
\hline Cyprus & - & - & - & 130 & 75.7 & 1.3 & 21.5 & 1.4 & 128 & 11.6 & 1 & 36 & 9.7 \\
\hline Egypt & 205 & 99.7 & 0.3 & 216 & 20.1 & 14.2 & 65.0 & 0.7 & 204 & 13.4 & 2 & 28 & 5.0 \\
\hline England & - & - & - & 86 & 25.6 & 7.3 & 50.1 & 17.0 & 86 & 15.9 & 1 & 42 & 11.7 \\
\hline Estonia & 137 & 94.5 & 5.5 & 143 & 27.3 & 14.3 & 51.0 & 7.4 & 147 & 22.2 & 1 & 50 & 12.5 \\
\hline Ghana & 119 & 78.0 & 22.0 & 129 & 27.4 & 19.9 & 29.4 & 23.3 & 136 & 7.8 & 1 & 33 & 7.0 \\
\hline Hong Kong & 115 & 81.6 & 18.4 & 129 & 19.1 & 13.4 & 42.1 & 25.3 & 126 & 11.8 & 1 & 35 & 9.0 \\
\hline Hungary & - & - & - & 151 & 5.9 & 57.3 & 33.9 & 2.9 & 148 & 21.9 & 1 & 46 & 9.9 \\
\hline Indonesia & 149 & 100.0 & 0.0 & 148 & 12.6 & 34.9 & 44.8 & 7.7 & 142 & 13.2 & 1 & 29 & 6.9 \\
\hline Iran & 142 & 85.1 & 14.9 & 175 & 57.2 & 10.3 & 21.4 & 11.1 & 172 & 14.0 & 1 & 36 & 8.0 \\
\hline Israel & 127 & 99.1 & 0.9 & 139 & 22.2 & 18.2 & 53.2 & 6.5 & 139 & 14.8 & 1 & 39 & 8.3 \\
\hline Italy & 201 & 100.0 & 0.0 & 216 & 20.9 & - & - & 79.1 & 202 & 22.4 & 1 & 36 & 8.4 \\
\hline Japan & 133 & 99.3 & 0.7 & 141 & 29.2 & 6.8 & 51.9 & 12.1 & 146 & 16.7 & 1 & 42 & 8.6 \\
\hline Jordan & 107 & 97.8 & 2.2 & 139 & 66.7 & 22.0 & 6.0 & 5.3 & 139 & 10.4 & 1 & 37 & 7.7 \\
\hline Korea & 136 & 98.7 & 1.3 & 139 & 33.0 & 54.3 & 8.0 & 4.8 & 136 & 12.8 & 1 & 32 & 7.7 \\
\hline Latvia & - & - & - & 142 & 15.4 & 1.2 & 82.5 & 0.9 & 143 & 22.2 & 3 & 46 & 10.7 \\
\hline Lithuania & 202 & 100.0 & 0.0 & 203 & 60.6 & 5.7 & 32.6 & 1.1 & 206 & 20.4 & 1 & 50 & 10.6 \\
\hline Macedonia & 63 & 25.1 & 74.9 & 145 & 50.2 & 31.2 & 8.4 & 10.2 & 142 & 20.4 & 1 & 39 & 10.9 \\
\hline Malaysia & 135 & 86.0 & 14.0 & 149 & 17.2 & 19.7 & 28.1 & 35.0 & 148 & 10.6 & 1 & 35 & 8.3 \\
\hline Moldova & 130 & 91.4 & 8.6 & 129 & 51.6 & 5.9 & 36.7 & 5.8 & 129 & 26.0 & 1 & 50 & 10.5 \\
\hline Morocco & 72 & 100.0 & 0.0 & 56 & 65.2 & 12.1 & 5.4 & 17.3 & 66 & 18.2 & 1 & 30 & 6.9 \\
\hline Netherlands & - & - & - & 124 & 12.1 & 32.6 & 33.6 & 21.6 & 120 & 17.0 & 1 & 37 & 10.5 \\
\hline New Zealand & 153 & 79.3 & 20.7 & 161 & 32.7 & 5.9 & 19.8 & 41.5 & 154 & 14.9 & 1 & 37 & 9.9 \\
\hline Norway & 154 & 100.0 & 0.0 & 148 & 32.5 & 0.5 & 2.1 & 64.9 & 166 & 18.3 & 1 & 41 & 11.5 \\
\hline Palestine & 105 & 88.5 & 11.5 & 141 & 46.7 & 32.8 & 4.5 & 16.0 & 131 & 9.9 & 1 & 36 & 8.0 \\
\hline Philippines & 121 & 94.4 & 5.6 & 133 & 37.7 & 29.1 & 22.8 & 10.4 & 130 & 11.5 & 1 & 37 & 8.6 \\
\hline Romania & 173 & 96.1 & 3.9 & 170 & 73.8 & 1.1 & 22.2 & 2.8 & 171 & 23.9 & 1 & 43 & 11.9 \\
\hline Russia & 204 & 100.0 & 0.0 & 213 & 95.7 & - & - & 4.3 & 207 & 22.6 & 1 & 49 & 11.0 \\
\hline Saudi Arabia & 146 & 97.3 & 2.7 & 149 & 34.0 & 6.7 & 59.3 & 0.0 & 146 & 9.5 & 1 & 38 & 8.1 \\
\hline Scotland & - & - & - & 133 & 30.8 & 12.9 & 44.9 & 11.3 & 127 & 16.5 & 1 & 35 & 10.1 \\
\hline Serbia & 158 & 89.4 & 10.6 & 163 & 37.9 & 2.2 & 56.1 & 3.8 & 163 & 21.6 & 1 & 45 & 12.1 \\
\hline Singapore & 288 & 100.0 & 0.0 & 303 & 32.7 & 4.1 & 53.3 & 10.0 & 294 & 11.9 & 1 & 48 & 12.3 \\
\hline $\begin{array}{l}\text { Slovak } \\
\quad \text { Republic }\end{array}$ & 175 & 93.8 & 6.2 & 179 & 30.5 & 29.7 & 30.0 & 9.7 & 178 & 20.8 & 1 & 48 & 12.3 \\
\hline Slovenia & 160 & 95.1 & 4.9 & 166 & 27.1 & 19.7 & 52.5 & 0.7 & 166 & 19.7 & 1 & 37 & 8.5 \\
\hline South Africa & 197 & 50.5 & 49.5 & 221 & 38.8 & 12.3 & 29.1 & 19.8 & 219 & 11.3 & 1 & 36 & 7.3 \\
\hline Sweden & 207 & 100.0 & 0.0 & 249 & 20.9 & 14.8 & 40.5 & 23.8 & 250 & 14.2 & 1 & 41 & 12.2 \\
\hline Syria & 66 & 70.3 & 29.7 & 84 & 22.9 & 11.9 & 59.6 & 5.6 & 85 & 10.3 & 1 & 30 & 6.5 \\
\hline Taiwan & 145 & 98.0 & 2.0 & 149 & 22.8 & 5.1 & 56.4 & 15.6 & 148 & 13.6 & 1 & 40 & 10.2 \\
\hline Tunisia & 138 & 92.8 & 7.2 & 148 & 53.7 & 9.7 & 29.0 & 7.5 & 98 & 12.2 & 1 & 36 & 9.8 \\
\hline United States & 316 & 95.1 & 4.9 & 328 & 17.5 & 24.7 & 28.2 & 29.7 & 332 & 14.3 & 1 & 50 & 10.2 \\
\hline$M$ & & 91.1 & 8.9 & & 36.1 & 15.2 & 34.1 & 14.6 & & 15.9 & & & \\
\hline
\end{tabular}

Note. Flemish Belgium refers to the Flemish-speaking population in Belgium. The data on certification are not available from Flemish Belgium, Cyprus, England, Hungary, Latvia, the Netherlands, or Scotland. The data on math education major are not available from Flemish Belgium, Italy, or Russia. 
APPENDIX B

Descriptive Statistics of Teacher Quality Variables at Student Level

\begin{tabular}{|c|c|c|c|c|c|c|c|c|c|c|c|}
\hline \multirow[b]{2}{*}{ Country } & \multicolumn{3}{|c|}{ Certification } & \multicolumn{5}{|c|}{ Math/Math Education Major } & \multicolumn{3}{|c|}{ Teaching Experience } \\
\hline & $\begin{array}{c}\text { Total } \\
n\end{array}$ & $\begin{array}{c}\text { Certified } \\
\%\end{array}$ & $\begin{array}{c}\text { Not } \\
\text { Certified } \\
\%\end{array}$ & $\begin{array}{c}\text { Total } \\
n\end{array}$ & $\begin{array}{c}\text { Math } \\
\text { Major } \\
\%\end{array}$ & $\begin{array}{c}\text { Math } \\
\text { Education } \\
\text { Major } \\
\%\end{array}$ & $\begin{array}{c}\text { Both } \\
\text { Majors } \\
\text { \% }\end{array}$ & $\begin{array}{l}\text { No } \\
\text { Major } \\
\%\end{array}$ & $\begin{array}{c}\text { Total } \\
n\end{array}$ & $\begin{array}{c}\text { Less Than } \\
3 \text { Years } \\
\%\end{array}$ & $\begin{array}{c}3 \text { or More } \\
\text { Years } \\
\%\end{array}$ \\
\hline Armenia & 3,776 & 100.0 & 0.0 & 4,207 & 45.2 & 6.0 & 39.4 & 9.4 & 3,858 & 0.0 & 100.0 \\
\hline Australia & 4,129 & 96.2 & 3.8 & 4,531 & 15.8 & 13.3 & 45.7 & 25.2 & 4,374 & 8.9 & 91.1 \\
\hline Bahrain & 3,927 & 87.4 & 12.6 & 4,175 & 8.8 & 49.1 & 40.1 & 2.0 & 3,784 & 12.9 & 87.1 \\
\hline Flemish Belgium & - & - & - & 4,807 & 95.9 & - & - & 4.1 & 4,785 & 7.7 & 92.3 \\
\hline Botswana & 4,427 & 100.0 & 0.0 & 4,660 & 45.0 & 19.1 & 32.1 & 3.8 & 4,315 & 21.6 & 78.4 \\
\hline Bulgaria & 3,704 & 100.0 & 0.0 & 4,040 & 16.2 & 1.2 & 80.4 & 2.2 & 3,951 & 2.2 & 97.8 \\
\hline Chile & 5,621 & 93.6 & 6.4 & 6,255 & 34.4 & 10.3 & 18.5 & 36.8 & 6,191 & 2.4 & 97.6 \\
\hline Cyprus & - & - & - & 3,869 & 76.0 & 1.7 & 21.7 & 0.6 & 3,857 & 14.4 & 85.6 \\
\hline Egypt & 6,691 & 99.7 & 0.3 & 7,065 & 21.1 & 14.9 & 64.0 & 0.0 & 6,658 & 0.9 & 99.1 \\
\hline England & - & - & - & 1,990 & 24.8 & 7.2 & 50.8 & 17.2 & 1,971 & 10.3 & 89.7 \\
\hline Estonia & 3,566 & 94.5 & 5.5 & 3,779 & 26.6 & 14.4 & 53.3 & 5.7 & 3,856 & 4.2 & 95.8 \\
\hline Ghana & 3,881 & 77.1 & 22.9 & 4,302 & 29.5 & 25.2 & 27.9 & 17.4 & 4,548 & 28.4 & 71.6 \\
\hline Hong Kong & 4,261 & 81.5 & 18.5 & 4,757 & 19.5 & 13.8 & 42.4 & 24.3 & 4,670 & 12.7 & 87.3 \\
\hline Hungary & - & - & - & 2,894 & 5.7 & 57.0 & 35.2 & 2.1 & 2,849 & 3.4 & 96.6 \\
\hline Indonesia & 5,725 & 100.0 & 0.0 & 5,671 & 14.6 & 36.4 & 44.2 & 4.8 & 5,465 & 5.3 & 94.7 \\
\hline Iran & 3,873 & 85.0 & 15.0 & 4,792 & 55.2 & 10.0 & 22.6 & 12.2 & 4,725 & 5.8 & 94.2 \\
\hline Israel & 2,356 & 98.7 & 1.3 & 2,566 & 25.3 & 18.1 & 49.3 & 7.3 & 2,564 & 5.3 & 94.7 \\
\hline Italy & 3,991 & 100.0 & 0.0 & 4,278 & 20.8 & - & - & 79.2 & 4,030 & 3.4 & 96.6 \\
\hline Japan & 4,423 & 99.3 & 0.7 & 4,698 & 30.2 & 7.1 & 50.5 & 12.2 & 4,856 & 3.7 & 96.3 \\
\hline Jordan & 3,408 & 97.5 & 2.5 & 4,453 & 67.7 & 23.7 & 4.6 & 4.0 & 4,453 & 13.5 & 86.5 \\
\hline Korea & 2,271 & 99.1 & 0.9 & 2,310 & 30.4 & 54.4 & 10.0 & 5.2 & 2,282 & 8.5 & 91.5 \\
\hline Latvia & - & - & - & 3,076 & 15.7 & 1.9 & 82.4 & 0.0 & 3,074 & 0.0 & 100.0 \\
\hline Lithuania & 4,693 & 100.0 & 0.0 & 4,667 & 59.2 & 7.7 & 33.1 & 0.0 & 4,755 & 2.2 & 97.8 \\
\hline Macedonia & 1,663 & 25.9 & 74.1 & 3,788 & 51.6 & 31.3 & 8.4 & 8.7 & 3,732 & 4.8 & 95.2 \\
\hline Malaysia & 4,811 & 86.7 & 13.3 & 5,293 & 18.1 & 20.1 & 27.8 & 34.0 & 5,244 & 14.7 & 85.3 \\
\hline Moldova & 3,151 & 91.1 & 8.9 & 3,144 & 51.6 & 8.0 & 35.9 & 4.5 & 3,116 & 2.1 & 97.9 \\
\hline Morocco & 1,527 & 100.0 & 0.0 & 1,195 & 67.0 & 10.9 & 6.1 & 16.0 & 1,430 & 3.3 & 96.7 \\
\hline Netherlands & - & - & - & 2,902 & 14.4 & 32.4 & 35.0 & 18.2 & 2,805 & 6.5 & 93.5 \\
\hline New Zealand & 2,870 & 76.8 & 23.2 & 3,002 & 31.4 & 5.6 & 18.5 & 44.5 & 2,888 & 16.3 & 83.7 \\
\hline Norway & 3,619 & 100.0 & 0.0 & 3,502 & 35.1 & 0.5 & 2.3 & 62.1 & 3,918 & 8.0 & 92.0 \\
\hline Palestine & 3,894 & 90.3 & 9.7 & 5,193 & 46.0 & 37.4 & 5.2 & 11.4 & 4,852 & 17.7 & 82.3 \\
\hline Philippines & 6,217 & 94.6 & 5.4 & 6,777 & 38.9 & 30.1 & 23.5 & 7.5 & 6,559 & 13.3 & 86.7 \\
\hline Romania & 4,000 & 96.5 & 3.5 & 3,956 & 73.8 & 1.3 & 22.7 & 2.2 & 3,928 & 3.3 & 96.7 \\
\hline Russia & 4,425 & 100.0 & 0.0 & 4,630 & 95.6 & - & - & 4.4 & 4,512 & 1.7 & 98.3 \\
\hline Saudi Arabia & 3,967 & 96.9 & 3.1 & 4,073 & 36.1 & 6.7 & 57.2 & 0.0 & 3,995 & 18.3 & 81.7 \\
\hline Scotland & - & - & - & 3,018 & 30.6 & 14.4 & 45.3 & 9.7 & 2,828 & 10.5 & 89.5 \\
\hline Serbia & 3,990 & 90.5 & 9.5 & 4,093 & 40.2 & 4.2 & 55.4 & 0.2 & 4,118 & 7.1 & 92.9 \\
\hline Singapore & 5,642 & 100.0 & 0.0 & 5,950 & 32.9 & 3.9 & 52.8 & 10.4 & 5,774 & 25.0 & 75.0 \\
\hline Slovak Republic & 4,114 & 93.6 & 6.4 & 4,215 & 30.1 & 31.9 & 29.4 & 8.6 & 4,185 & 8.7 & 91.3 \\
\hline Slovenia & 3,109 & 94.6 & 5.4 & 3,235 & 27.2 & 18.3 & 53.7 & 0.8 & 3,225 & 3.9 & 96.1 \\
\hline South Africa & 6,764 & 49.7 & 50.3 & 7,710 & 41.0 & 13.0 & 27.1 & 18.9 & 7,623 & 12.5 & 87.5 \\
\hline Sweden & 3,351 & 100.0 & 0.0 & 3,998 & 21.9 & 14.2 & 44.8 & 19.1 & 3,994 & 16.3 & 83.7 \\
\hline Syria & 2,528 & 72.0 & 28.0 & 3,208 & 24.5 & 11.7 & 59.6 & 4.2 & 3,246 & 20.3 & 79.7 \\
\hline Taiwan & 5,180 & 98.2 & 1.8 & 5,337 & 22.3 & 5.5 & 57.4 & 14.8 & 5,257 & 13.5 & 86.5 \\
\hline Tunisia & 4,541 & 92.8 & 7.2 & 4,898 & 53.9 & 9.9 & 28.8 & 7.4 & 3,203 & 15.0 & 85.0 \\
\hline United States & 7,626 & 95.4 & 4.6 & 7,849 & 19.1 & 27.1 & 28.2 & 25.6 & 7,880 & 9.2 & 90.8 \\
\hline$M$ & & 91.2 & 8.8 & & 36.7 & 16.0 & 34.2 & 13.2 & & 9.3 & 90.7 \\
\hline
\end{tabular}

Note. Flemish Belgium refers to the Flemish-speaking population in Belgium. The data on certification are not available from Flemish Belgium, Cyprus, England, Hungary, Latvia, the Netherlands, or Scotland. The data on math education major are not available from Flemish Belgium, Italy, or Russia. 